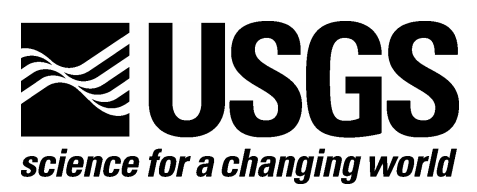

\title{
Dialog on Science Impact: Benchmarking External Efforts and Organizations
}

By Nathan Wood

Report Series 2006-1013

U.S. Department of the Interior U.S. Geological Survey 


\section{U.S. Department of the Interior \\ Gale A. Norton, Secretary}

\section{U.S. Geological Survey \\ P. Patrick Leahy, Acting Director}

U.S. Geological Survey, Reston, Virginia, 2006

For product and ordering information:

World Wide Web: http://www.usgs.gov/pubprod

Telephone: 1-888-ASK-USGS

For more information on the USGS - the Federal source for science about the Earth, its natural and living resources, natural hazards, and the environment:

World Wide Web: http://www.usgs.gov/

Telephone: 1-888-ASK-USGS

Suggested citation: Wood, Nathan, 2006, Dialog on Science Impact: Benchmarking External Efforts and Organizations: Menlo Park, CA.

Any use of trade, product, or firm names is for descriptive purposes only and does not imply endorsement by the U.S. Government.

Although this report is in the public domain, permission must be secured from the individual copyright owners to reproduce any copyrighted material contained within this report. 


\section{Contents}

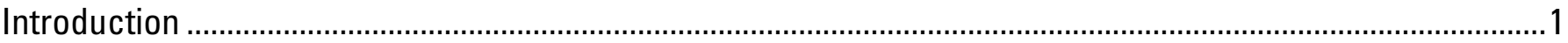

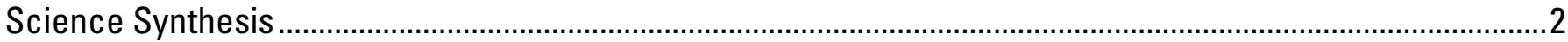

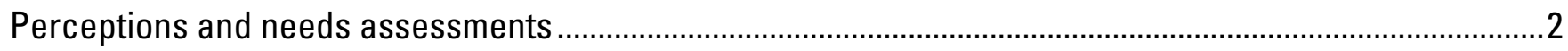

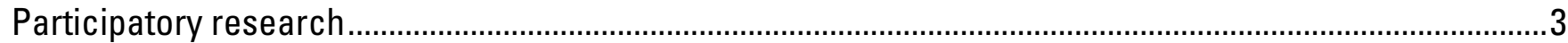

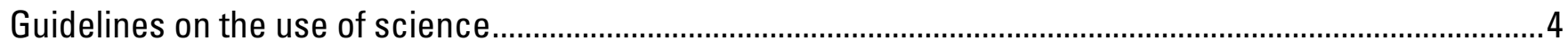

Nonresearch mechanisms to facilitate integration....................................................................................

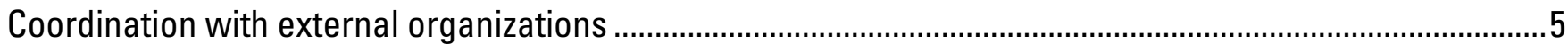

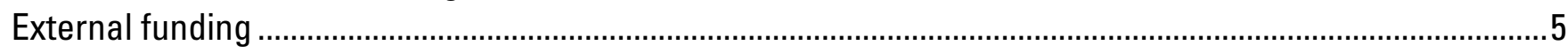

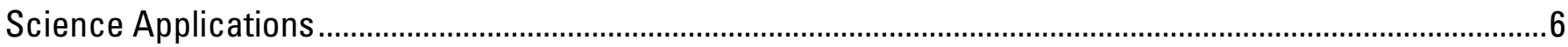

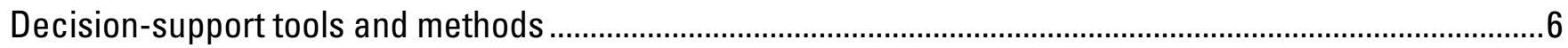

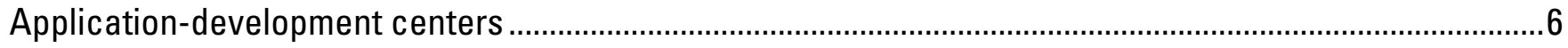

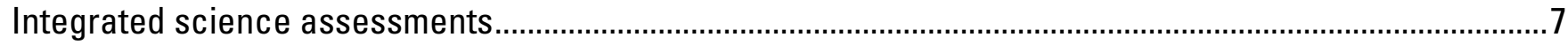

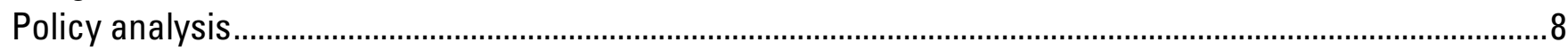

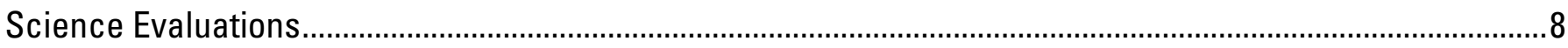

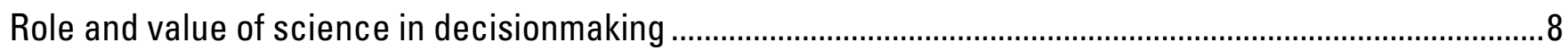

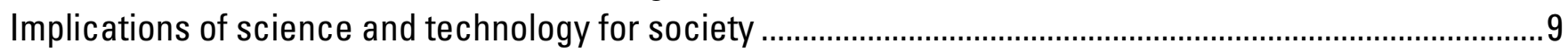

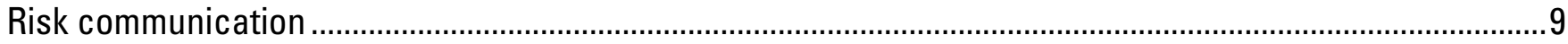

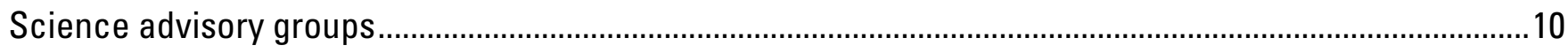

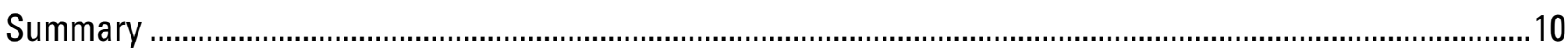

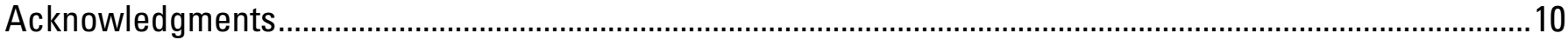

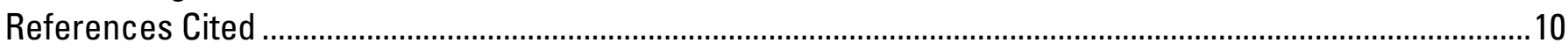

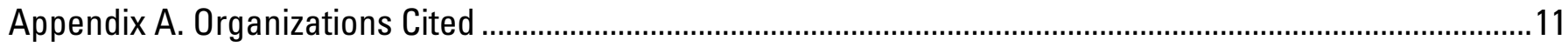

Appendix B. Summaries of Individual Organizations ...................................................................................... 


\title{
Dialog on Science Impact: Benchmarking External Efforts and Organizations
}

\author{
By Nathan Wood
}

\section{Introduction}

This report summarizes the efforts of organizations external to the U.S. Geological Survey (USGS) that focus on improving the use of science to support societal decisionmaking. This information was collected to provide the USGS with additional program ideas and potential avenues for collaboration as it develops the Science Impact Program (USGS 2005).

The Science Impact Program, a research program dedicated to increasing the use and value of USGS science in societal decisionmaking, is a focused effort by the USGS to enhance its program performance and science delivery in support of the Department of the Interior's "Four C's": consultation, cooperation, and communication - all in the service of conservation (DOI 2003). The benchmarking effort described in this report is a first step for the USGS toward consulting other federal agencies and nations, as well as academic groups and the private sector, to exchange ideas and best practices for improving the use of science in decisionmaking. The USGS can then cooperate with external organizations in areas of mutual interest so as to develop new ways to communicate the best available science. This integrated and collaborative approach will increase the relevance, utility, and customer value of USGS science.

The USGS has much to learn from external organizations, such as about the organizational frameworks of research/application-development centers and guidelines on the use of science in societal decisionmaking. Federal agencies take various approaches to expand the use of science in decisionmaking, including the establishment of application centers (e.g. the National Oceanic and Atmospheric Administration [NOAA]'s Coastal Services Center) and science-policy councils headed by science advisors (e.g., the Environmental Protection Agency). Much documentation is also available from European organizations and agencies that focus on the science/society interface.

Data for this study, which were collected in the summer of 2004 via an Internet search, are organized in this report by the three primary activities of the USGS Science Impact Program:

- science synthesis;

- $\quad$ science applications; and

- science evaluations.

Keywords used in the Internet search included "science-society," "science impact," and "science and decisionmaking.” The types of external organizations included in this search are academic departments, nonprofit organizations, State and local governments, federal agencies, other nations, and international organizations. The main body of this report describes common themes observed in the various efforts, in which each of the subsequent sections focuses on one of the three primary activities of the Science Impact Program. For additional information on a specific organization, see Appendix A, which lists organization web-sites for quick reference, and Appendix B, which provides detailed overviews of individual organizations. 
This report is not an exhaustive list of efforts, but a first step toward what the USGS Science Impact Program must continue to do every year as it matures. An annual review of external benchmarking conducted by the Science Impact Program Coordinator's office will provide the program with new ideas and contacts for collaboration on projects. Increased communication, collaboration, and coordination with related agencies in the Federal community, State and local governments, and other nations on the issue of improving the science/society interface directly supports the Department of the Interior's aim for results-oriented performance goals (DOI 2003).

After identifying external efforts, the Science Impact Program needs to collaborate with some of the organizations listed in this report in order to examine and evaluate what makes for a successful use of science in societal decisionmaking. This evaluation of the societal impact of science would allow the program to begin to formulate a successful strategy for integrating science with societal decisionmaking. Note that Science Impact Partnership Universities (USGS 2005), established to provide specialized skills for the Science Impact Program, are not included in this external benchmarking because they are now part of the overall program.

\section{Science Synthesis}

Science-synthesis activities of the USGS Science Impact Program include the development, testing, evaluation, and application of methods and processes to facilitate an expanded and more effective use of USGS science to inform societal decisionmaking. Societal issues, disputes, and problems are linked with current and future science capabilities to determine the context within which science can most effectively support decisionmaking. Collaborative processes are used to define the research questions that need to be answered to provide effective solutions.

\section{Perceptions and needs assessments}

Various organizations have research programs to assess the needs and opportunities for science in support of decisionmaking. Because decisionmakers' perceptions are a major influence on the context within which science is used, many organizations also conduct general landscape and risk perception studies. For example:

- The Mineral Management Service’s Environmental Studies Program conducts issuesidentification studies related to oil and gas development on the Outer Continental Shelf. These studies include the identification of the various stakeholders, their issues and concerns toward the environment, risk assessment, opportunities for public involvement, areas of potential conflict and resolution, and significant issues for further research.

- $\quad$ The U.S. Forest Service Focused Science Delivery (FSD) Program holds formal discussions biennially with policymakers and managers to select upcoming topics for the FSD Program.

- $\quad$ The NOAA Coastal Services Center conducts a survey every 2 years that focuses on the issues and needs of its customers, including the types of needed training and geographic-informationsystem (GIS)-based applications that need to be developed.

- The U.K. Climate Impacts Program (UKCIP) of the University of Oxford's Department for Environment, Food, and Rural Affairs conducts studies of climate-change impacts as commissioned by stakeholders, including the formulation of research agendas.

In addition, the Oregon Natural Hazards Workgroup, the National Park Service's Nature and Science Program, the Scottish Universities Policy Research and Advice Network, the Center for Science and Technology Policy Research at the University of Colorado - Boulder, the 
Environmental and Societal Impacts Group of the National Center for Atmospheric Research, the National Science and Technology Center of the Bureau of Land Management, the New Zealand Ministry of Research, Science, and Technology’s Science in Society program, the Centre for Research into Innovation, Culture, and Technology at Brunel University, the Consortium for Science, Policy \& Outcomes at Arizona State University and the Policy Studies Institute Environmental Group at the University of Westminster all conduct research on the decision-support role of science. Additional information on each of these organizations is provided in Appendix B.

\section{Participatory research}

Another avenue for determining the context within which science can most effectively support decisionmaking is to integrate science into societal decisionmaking and planning processes. Many models for this collaboration exist throughout the world, some of which are based on participatory research, while others are training opportunities. For example:

- Training science facilitators to bridge the gap between researchers and managers. The Gulf of Maine Council on the Marine Environment's Science Translation Project focuses on training "science translators" to work with resource managers, planners, and policymakers. The Center for Science and Technology Policy Research of the Cooperative Institute for Research in Environmental Sciences at the University of Colorado-Boulder is implementing the concept of "information brokers" to improve the relevance and use of science in decisionmaking, specifically with regard to operational hydroclimate products.

- Workshops to integrate science and planning. The Oregon Natural Hazards Workgroup has organized a year-long suite of workshops focusing on city and county all-hazard mitigation planning and including USGS researchers in these workshops. The NOAA Coastal Services Center has established a Coastal Learning Center that includes a training facility in Charleston, SC, as well as the capacity to send trainers and facilitators throughout the world. Topics include the use of geospatial data in decisionmaking and coastal-management planning.

- Centers for public/researcher interaction. To provide opportunities both for the public to better understand science and for the researcher to better understand societal issues and needs. Science Shops have been coordinated under the Science and Society theme of the European Commission's European Research Area (EUROPA) and the National Park Service's Research Learning Centers.

- Construction of models for interdisciplinary collaboration. The New Directions in the Earth Sciences and the Humanities initiative, directed by the Center for Science and Technology Policy at the University of Colorado, Boulder, and the Colorado School of Mines, is an effort to construct new collaborative models where physical scientists, social scientists, and humanists can work together with public science agencies, the private sector, and communities to deepen understanding of, and promote effective responses to, environmental problems. The U.S. Forest Service Focused Science Delivery Program is developing ways to increase collaboration among researchers, policymakers, managers and the public for addressing complex resource management issues. The Deliberative Mapping Project of the Policy Studies Institute Environmental Group at the University of Westminster examines how scientific, expert-driven risk-assessment techniques can be reconciled with deliberative approaches to public consultation.

In addition, the Natural Hazards Center at the University of Colorado, Boulder, and its yearly conference for researchers and practitioners, the U.K. Climate Impacts Program, the Scottish 
Universities Policy Research and Advice Network, the New Zealand Ministry of Research, Science and Technology's Science in Society Program, the Centers for Disease Control and Prevention's Office of Science Policy and Technology Transfer, the Federation of Earth Science Information Partners, the U.K. Engineering and Physical Sciences Research Council's Public Engagement Programme, and the Environmental and Societal Impacts Group of the National Center for Atmospheric Research all conduct participatory research. Additional information on each of these organizations is provided in Appendix B.

\section{Guidelines on the use of science}

Various organizations have published guidelines on topics related to the improved use of science in society. The USGS Science Impact Program will benefit from learning about these efforts and developing similar guidelines. For example:

- Under its The Science and Society theme, the European Commission's European Research Area (EUROPA) has published guidelines on such topics as principles and guidelines for scientists, public participation, public trust in scientific information, and action plans for integrating science and society.

- The U.K. Department of Trade and Industry's Office of Science and Technology has published guidelines on public participation in science and technology and the use of science in policymaking.

- The Environmental Protection Agency’s report “Science to Support Rulemaking” (OIG 2002) addresses the role of science, the genesis of this science, and the extent to which the science was peer reviewed.

- The Council for Excellence in Government and the Committee for Economic Development have published guidelines on the integration of government research into societal decisionmaking.

\section{Nonresearch mechanisms to facilitate integration}

Many organizations are implementing nonresearch mechanisms to improve accessibility to their information. Similar, nonresearch actions can be taken by the USGS to facilitate and expand the use of its science. For example:

- A searchable database of identified experts that allows the public to directly link to researchers and their project websites. Duke University's Nicholas School of the Environment and the Scientific Information for Policy Support in Europe (SINAPSE) project coordinated under the Science and Society theme of the European Commission's European Research Area (EUROPA) are particularly noteworthy. SINAPSE is a toolkit that facilitates scientific coordination and collaboration in Europe, including a scientific "yellow pages" and a library of scientific opinions.

- Contextual information on the Federal policy process as it pertains to scientific issues. The American Society of Limnology and Oceanography has a Web site (http://aslo.org/policy/aslo.html) for its members that provides researchers with a contextual overview of how their research efforts are incorporated into the science-policy arena.

- An explorer database that allows users to link to project Web sites, access progress reports, get researcher contact information, and learn about programs. The Web site of the Cooperative Institute for Coastal and Estuarine Environmental Technology (http://www.ciceet.unh.edu/index_flash.html) is one such resource. 
- Colocation of researchers with management groups. The Cooperative Ecosystems Studies Unit (CESU) initiative is an employee-colocation program designed to supply resource managers with research data and to maintain partnerships among Federal agencies and universities to share scientific resources and expertise. The USGS is a participating member in the CESU initiative, and the USGS Science Impact Program could become more directly involved.

\section{Coordination with external organizations}

Many organizations focus on improving the integration of other organizations' science into societal decisionmaking. To complement its research agenda on improving and expanding the use its science, the USGS should continue to foster relationships and seek to build new ones. For example, the Natural Hazards Caucus Workgroup strives to promote a wider understanding within Congress that reducing the risks and costs of natural disasters is a public value. The workgroup supports the efforts of the Congressional Natural Hazards Caucus, a partnership established under the leadership of co-chairs Senator Ted Stevens (AK) and Senator John Edwards (NC), to provide members with an opportunity to demonstrate their concern and commitment to reducing hazard losses.

In addition, the National Council for Science and the Environment, the Center for Science, Technology, and Congress of the American Association for the Advancement of Science, the American Geological Institute's Government Affairs Program, the President's Office of Science and Technology Policy, the American Geophysical Union's Science and Policy Program and the National Park Service's Nature and Science Program all promote the use of science in societal decisionmaking. Additional information on each of these organizations is provided in Appendix B.

\section{External funding}

To foster greater science-impact innovation, many agencies fund external agencies and organizations. The USGS Science Impact Program, which continues this trend by establishing Science Impact Partnership Universities, can learn from these efforts. For example:

- $\quad$ The Science and Technology Directorate of the Department of Homeland Security has established Homeland Security Centers of Excellence and National Research Centers, such as the National Visual Analytics Center at Pacific Northwest National Laboratory.

- Under its Earth Science Applications theme, the NASA Earth Science Enterprise (ESE) funds Affiliated Research Centers, Regional Earth Science Applications Centers, a National Oceanographic Partnership Program, and Small Business Innovation Research, as well as individual researchers at academic institutions.

- The Cooperative Institute for Coastal and Estuarine Environmental Technology is a partnership between the NOAA and the University of New Hampshire (UNH) to use the capabilities of UNH, the private sector and academic and public research institutions throughout the United States, as well as the 26 reserves in the National Estuarine Research Reserve System (NERRS), to develop new environmental technologies and applications.

- $\quad$ The NOAA Coastal Services Center supports public- and private-sector practitioners for application-development projects in an annual proposal-driven funding program.

- The Centers for Disease Control and Prevention's Office of Science Policy and Technology Transfer funds 12 research centers across the country, as well as a series of outreach programs based on Centers for Disease Control and Prevention research, including a Bioterrorism Preparedness and Response Program. 


\section{Science Applications}

Science-application activities of the USGS Science Impact Program include the development, testing, evaluation, and application of multidisciplinary tools and products to integrate USGS science with other relevant factors, including socioeconomic information, to more effectively inform decisionmaking.

\section{Decision-support tools and methods}

One of the primary elements of the USGS Science Impact Program is the creation of tools and methods that directly support societal decisionmaking. This element has long been a component of other organizations' programs. For example:

- The Enterprise Development Impact Assessment Information Service (EDIAIS) provides a toolbox for resource managers that includes information and guidelines for participatory learning, stakeholder and value analysis, quantitative and qualitative methods, indicator development, and translating information to influence change. The EDIASIS is a joint project of the Institute for Development Policy and Management (IDPM) at Manchester University and Women in Sustainable Enterprise (WISE) Development Ltd.

- The Environmental and Societal Impacts Group of the University Corporation for Atmospheric Research at its National Center for Atmospheric Research is creating tools for handling uncertainty in meteorologic-risk assessments as a part of its project on "Climate Variability and Uncertainty in Flood Hazard Planning in Colorado.”

- The U.K. Climate Impacts Programme (UKCIP) at the University of Oxford has created tools to help organizations assess the effect of potential climate change. The UKCIP Adaptation Wizard is a decision-support tool designed to help a person from simple understanding of climate change to integration of climate-change issues into decision-making. The Scenarios Gateway, another UKCIP tool, provides access to climate-change-scenario data, as well as information and guidance on the use of these data-sets.

- The Pacific Disaster Center, a public/private partnership managed by the East-West Center in Maui, Hawaii, has created the Asia Pacific Natural Hazards and Vulnerabilities Atlas, an online mapping application that combines baseline geographic and infrastructure data layers with historical and near-real-time data on natural hazard events including earthquakes, tsunamis, volcanoes, and tropical storms. The center serves as an information clearinghouse for the entire Pacific Basin.

- The Centers for Disease Control and Prevention has created a series of indicators and conducts monitoring programs to support decisionmaking related to human health, including the National Vital Statistics System, the Morbidity and Mortality Weekly Report, and the Behavioral Risk Factor Surveillance System.

\section{Application-development centers}

In addition to creating specific tools and methods that directly support societal decisionmaking, some organizations have established centers of excellence that focus on application development. For example:

- The NOAA Coastal Services Center in Charleston, SC, was established to support the environmental, social, and economic well being of the coast by linking people, information, and technology. The center conducts research and application-development programs in remote sensing, GIS, and landscape characterization. 
- The Pacific Disaster Center provides support for applied information research and analysis to disaster-management and humanitarian-assistance communities in the Asia Pacific region and beyond, with funding from Department of Defense appropriations and from Asian and Pacific Governments, private agencies, individuals and corporations.

- Under its The Earth Science Applications theme, the NASA Earth Science Enterprise (ESE) benchmarks practical uses of NASA-sponsored observations from Earth observation systems and predictions from Earth-science models. ESE programs focus on applications of national priority to expand and accelerate the use of the science and technology resulting from ESE's goal of improving predictions in the areas of weather, climate, and natural hazards. The NASA Applications Research Division supplies Earth-science products for the advancement of earthsystem science in application to societal concerns. Primary projects include homeland security, energy management, public health, ecologic forecasting, water management, and scientific visualization. NASA funds Affiliated Research Centers to develop remote-sensing applications and Regional Earth Science Application Centers to conduct research on applied issues.

- The Bureau of Land Management's National Science and Technology Center provides science and technology applications to bureau offices.

In addition, the National Visual Analytics Center at the Department of Homeland Security's Pacific Northwest National Laboratory, the NOAA Cooperative Institute for Coastal and Estuarine Environmental Technology, and the University of New Hampshire all fund such application development. Additional information on each of these organizations is provided in Appendix B.

\section{Integrated science assessments}

One approach to improving the use of science in societal decisionmaking is to conduct research that requires the integration of natural and socioeconomic information. For example:

- The Environmental and Societal Impacts Group of the University Corporation for Atmospheric Research's National Center for Atmospheric Research has an active research program with numerous projects that focus on the integration of natural and socioeconomic research for addressing societal issues. The Wildland Fire Research and Development Collaboratory studies wildland-fire science, societal impacts, and operational applications and the Societal and Economic Impact subprogram of THe Observing System Research and Predictability EXperiment (THORPEX) is a 10-year international research program to improve forecasts of high-impact weather.

- The Center for Science and Technology Policy Research at the University of Colorado, Boulder, conducts numerous research projects that focus on providing alternatives for science and technology policymakers. One such project is "Carbon Cycle Science: Reconciling Supply and Demand," which attempts to map and assess the compatibility of the supply and demand sides of the carbon cycle.

In addition, the Stockholm Environmental Institute at the University of York, the Centers for Disease Control and Prevention's Office of Science Policy and Technology Transfer, the RAND Corp. Science and Technology Policy Institute, the Center for Health Policy, Law, and Management at Duke University, the Consortium for Science, Policy \& Outcomes at Arizona State University, the Leeds Institute of Environmental Science and Management at the University of Leeds, the Macaulay Institute of the U.K. Scottish Office, the Tyndall Center for Climate Change 
Research at the University of East Anglia, and the Policy Studies Institute - Environmental Group at the University of Westminster all conduct multi-disciplinary science studies.

\section{Policy analysis}

Another approach to improving the use of science in societal decisionmaking is to conduct research on current policy issues. Scientific information, mainly in the form of scenario generation, is then directly used in decision support. For example:

- $\quad$ The U.K. Office of Science and Technology's Foresight program aims to increase U.K. exploitation of science and provide future alternatives for decisionmakers. The program identifies potential opportunities for the economy or society from new science and technology, and actions to help realize those opportunities. Current topics include flood and coastal defense, cybertrust, exploiting the electromagnetic spectrum, and brain science and drugs.

- The RAND Corp. Science and Technology Policy Institute, created by act of Congress in 1991, is managed by the Institute of Defense Analysis and reports to the President's Office of Science and Technology Policy. It conducts policy analysis as well as studies on the science-andtechnology components of broader issues, such as homeland security and education.

- The National Institute of Health (NIH)'s Office of Science Policy and Planning (OSPP) conducts research on the economic impact of science policies. Research focuses on the contributions of NIH science to increased life expectancy, reduced costs of illness and injury, and economic growth.

- The U.S. Fish and Wildlife Service (FWS)'s Division of Economics provides technical assistance in support of the FWS' mission. Inhouse capabilities and experience include economic-impact analysis, policy analysis and legislative package and review assistance.

- The Marine Policy Center at the Woods Hole Oceanographic Institution (WHOI) conducts research that integrates economics, policy analysis, and law with WHOI's basic strengths in ocean science and engineering.

In addition, the Consortium for Science, Policy \& Outcomes at Arizona State University, the Center for Environment and Planning at the University of the West England, the Cooperative Institute for Research in Environmental Sciences' Center for Science and Technology Policy Research at the University of Colorado, Boulder, the Center for Health Policy Law and Management at Duke University, the Policy Studies Institute - Environmental Group at the University of Westminster, and the Center for International Science and Technology Policy in the Elliot School of International Affairs at George Washington University all conduct programs in science-policy analysis. Additional information on each of these organizations is provided in Appendix B.

\section{Science Evaluations}

The USGS Science Impact Program focuses on creating methods and conducting analyses to evaluate and measure the effectiveness of USGS science in informing societal decisionmaking.

\section{Role and value of science in decisionmaking}

An important element of understanding the social context of science is its role and value in decisionmaking. For example: 
- The Consortium for Science, Policy \& Outcomes’ Public Value Mapping project at Arizona State University seeks to develop tools and measures enabling a better understanding of the multiple factors in societal decisionmaking and the role of science as part of the web of institutions, networks, and groups giving rise to social impacts.

- The Environmental and Societal Impacts Group of the National Center for Atmospheric Research has an active research program that focuses on the use and value of science in decisionmaking, specifically for weather and climate issues.

In addition, the Center for Science and Technology Policy Research at the University of Colorado, Boulder, and the Policy Studies Institute - Environmental Group at the University of Westminster both study the social impact of science. Additional information on each of these organizations is provided in Appendix B.

\section{Implications of science and technology for society}

Several research programs focus on examining the implications of scientific and technological advances for society. For example, the Institute for Environment, Philosophy and Public Policy at Lancaster University brings together academics from philosophy and the social sciences to develop fresh crossdisciplinary thinking about the growing range of social and ethical issues thrown up by new scientific and technological developments.

In addition, the Space Policy Institute of the Center for International Science and Technology Policy in the Elliott School of International Affairs at George Washington University, the Centre for Research into Innovation, Culture and Technology of the Department of Human Sciences at Brunel University, the Center for Science, Policy, and Outcomes at Arizona State University, and the Center for Science and Technology Policy Research of the Cooperative Institute for Research in Environmental Sciences at the University of Colorado, Boulder have programs to study the implications of scientific and technological advances for society. Additional information on each of these organizations is provided in Appendix B.

\section{Risk communication}

All scientific studies include some degree of uncertainty in their results. However, resource managers and the general public must still make decisions by weighing the benefits and consequences of various actions in spite of this uncertainty. In fact, individuals and societies all perceive uncertainty differently. Therefore, research on risk communication and decisionmakers' ability to incorporate uncertainty are critical elements in creating methods to improve the impact and utility of USGS science. For example, the Annenberg School for Communication at the University of Pennsylvania and its Public Policy Center focus on the intersection of media, communication, and public policy with an active research program, lecture series, and roundtable discussions. Much of its research focuses on health risks, in collaboration with the Centers for Disease Control and Prevention.

In addition, the Environmental and Societal Impacts Group of the National Center for Atmospheric Research, the U.K. Climate Impacts Programme in the University of Oxford's Department of Environment, Food and Rural Affairs, the Center for Environmental Research and Training at the University of Birmingham, and the Scottish Universities Policy Research and Advice Network all conduct research of risk communication and perception. Additional information on each of these organizations is provided in Appendix B. 


\section{Science advisory groups}

To improve the interface between scientists and decisionmakers, many organizations have established internal science advisory groups that serve to assemble and integrate relevant scientific information to address pressing societal issues. For example:

- The Environmental Protection Agency's Science Policy Council is headed by the Office of the Science Advisor, which provides leadership in establishing specific mechanisms for ensuring that scientific results and hypotheses, with technical evaluation and peer review, play a prominent role in all regulatory decisions.

- The Office of Science Policy and Planning serves as a science advisory board for the National Institutes of Health.

In addition, the Australian Bureau of Rural Services, the Science and Technology Directorate of the Department of Homeland Security, the Office of Science Policy and Technology Transfer of the Centers for Disease Control and Prevention, and the National Science and Technology Center of the Bureau of Land Management all perform a science advisory function. Additional information on each of these organizations is provided in Appendix B.

\section{Summary}

This report summarizes efforts by various organizations external to the USGS to improve the use of science in support of societal decisionmaking. The information presented here should be used to provide the USGS with additional program ideas and potential avenues for collaboration as it develops its Science Impact Program. Again, this report is not an exhaustive list of efforts, but it offers an accurate snapshot of how other organizations are studying the impact of science on society. Archiving and evaluating the efforts of external organizations should be a continuous activity within the Science Impact Program, allowing the USGS to learn from others' experiences. Using the contact information contained in the following appendices, the Science Impact Program could establish a working group with other organizations who are interested in improving the science/society interface. This working group could meet yearly to coordinate and collaborate on projects of mutual interest, as well as to provide a forum for sharing best practices. I hope that this report will help inform USGS scientists about possible ways of bringing their science to decisionmakers and stakeholders and thereby further the aims of the Science Impact Program.

\section{Acknowledgments}

I thank the USGS Science Impact Program for funding this effort, as well as Kyle Gomez for his assistance in setting up a Microsoft Access database to serve as an archive for all of the information I gathered. Susan Benjamin, Nina Burkardt and Caroline Hermans provided insightful reviews of the manuscript.

\section{References Cited}

Office of the Inspector General, 2002, Science to support rulemaking: Environmental Protection Agency, Report 2003-P-00003.

U.S. Department of the Interior, 2003, Strategic plan, FY 2003 - 2008: Washington, D.C. [URL http://www.doi.gov/ppp/strat_plan_fy2003_2008.pdf].

U.S. Geological Survey, 2005, Science impact [URL http://www.usgs.gov/science_impact/]. 


\section{Appendix A. Organizations Cited}

This section lists the Web sites of the organizations mentioned in the text. This information is also provided in Appendix B within each individual organization summary.

American Society of Limnology and Oceanography

http://aslo.org/policy/aslo.html

Annenberg School for Communication, University of Pennsylvania

http://www.asc.upenn.edu/

Australian Bureau of Rural Services

http://www.affa.gov.au/brs/

Board on Science, Technology and Economic Policy - National Academy of Sciences

http://www7.nationalacademies.org/step/index.html

Center for Earth and Planetary Studies, Smithsonian Institution

http://www.nasm.si.edu/research/ceps/

Centre for Environment and Planning, University of the West of England

http://www.built-environment.uwe.ac.uk/research/cep/

Centre for Environmental Research and Training, University of Birmingham

http://www.cert.bham.ac.uk/

Center for Health Policy Law and Management, Duke University

http://www.hpolicy.duke.edu/

Center for International Science and Technology Policy, Elliot School of International Affairs, George Washington University

http://www.gwu.edu/ cistp/

Centre for Research into Innovation, Culture and Technology, Department of Human Sciences, Brunel University

http://www.brunel.ac.uk/depts/crict/

Center for Science and Technology Policy Research, Cooperative Institute for Research in Environmental Sciences, University of Colorado, Boulder http://sciencepolicy.colorado.edu/

- New Directions Project: http://newdirections.colorado.edu/

- Information Brokers: http://sciencepolicy.colorado.edu/wwa/intranet/oldthemes/info_brokers/

Center for Science, Technology, and Congress, American Association for the Advancement of Science http://www.aaas.org/spp/cstc/ 
Coastal Services Center, National Oceanic and Atmospheric Administration www.csc.noaa.gov

- GIS Integration and Development Program: http://www.csc.noaa.gov/id/

- Coastal Resource Management Customer Survey: http://www.csc.noaa.gov/survey/

- Coastal Learning Services: http://www.csc.noaa.gov/cms/cls/

Consortium for Science, Policy \& Outcomes - Arizona State University

http://www.cspo.org/

Cooperative Ecosystem Studies Unit

http://www.cesu.org/cesu/index.html

Cooperative Institute for Coastal and Estuarine Environmental Technology, National Oceanic and Atmospheric Administration and the University of New Hampshire http://www.ciceet.unh.edu/index_flash.html

Council for Excellence in Government http://excelgov.org/

- Report: Linking Resource to Results:

http://excelgov.org/displayContent.asp?NewsItemID=3976\&Keyword=ppStudies

Council of Scientific Society Presidents

http://www.cssp.us/

Department of Environmental Policy and Management Group, Imperial College London http://www.iccept.ic.ac.uk/public.html

Division of Economics, U.S. Fish and Wildlife Service http://economics.fws.gov/

Earth Science Enterprise, National Aeronautics and Space Agency http://www.nasa.gov/

- Earth Science Applications theme: http://www.earth.nasa.gov/eseapps/index.html

Enterprise Development Impact Assessment Information Service http://www.enterprise-impact.org.uk/

- Tool Box: http://www.enterprise-impact.org.uk/informationresources/toolbox.shtml

Environmental and Societal Impacts Group, National Center for Atmospheric Research http://www.esig.ucar.edu/

Environmental Protection Agency

http://www.epa.gov/

- Science Policy Council: http://www.epa.gov/osa 
European Commission

http://europa.eu.int/

- Science and Society theme: http://europa.eu.int/comm/research/sciencesociety/documents_en.html

- Scientific Information for Policy Support in Europe: http://europa.eu.int/sinapse

- Science Shops: http://europa.eu.int/comm/research/science-society/scientificawareness/shops_en.html

Federation of Earth Science Information Partners

http://www.esipfed.org/

U.S. Forest Service

http://www.fs.fed.us

- Focused Science Delivery Program: http://www.fs.fed.us/about/programs/fsd/

Government Affairs Program, American Geological Institute

http://www.agiweb.org/gap/

Gulf of Maine Council on the Marine Environment

http://www.gulfofmaine.org/

- Science Translation Project: http://www.gulfofmaine.org/science_translation/

H. John Heinz III Center for Science, Economics and the Environment

http://www.heinzctr.org/

Institute for Environment, Philosophy and Public Policy at Lancaster University, http://www.lancs.ac.uk/fss/ieppp/

Macaulay Institute, U.K. Scottish Office

http://www.mluri.sari.ac.uk/intro.htm

Marine Policy Center, Woods Hole Oceanographic Institution

http://www.whoi.edu/science/MPC/dept/index.html

Mineral Management Service

http://www.mms.gov

- Environmental Studies Program: http://www.mms.gov/eppd/env/

National Council for Science and the Environment

http://www.ncseonline.org/

National Park Service

http://www.nps.gov

- Nature and Science Program: http://www.nature.nps.gov/scienceresearch/

National Science and Technology Center, Bureau of Land Management 
http://www.blm.gov/nstc/

National Visual Analytics Center, Pacific Northwest National Lab

http://nvac.pnl.gov/

Natural Hazards Caucus Workgroup

http://www.agiweb.org/workgroup/

NATO Programme for Security Through Science

http://www.nato.int/science/

Natural Hazards Research and Applications Information Center, University of Colorado, Boulder http://www.colorado.edu/hazards/

New Zealand Ministry of Research, Science \& Technology

http://www.morst.govt.nz/

- Science in Society Program:

http://www.morst.govt.nz/?CHANNEL=SCIENCE+IN+SOCIETY\&PAGE=Science+in+Society

Nicholas School of the Environment, Duke University

http://www.env.duke.edu/people/faculty/

Office of Science and Technology Policy, Executive Office of the President http://www.ostp.gov/

Office of Science Policy and Planning, National Institutes of Health http://ospp.od.nih.gov/

Office of Science Policy and Technology Transfer, Centers for Disease Control and Prevention http://www.cdc.gov/od/ads/

Oregon Natural Hazards Workgroup

http://darkwing.uoregon.edu/ onhw/

Pacific Disaster Center

http://www.pdc.org/

- Asia Pacific Natural Hazards and Vulnerabilities Atlas:

http://atlas.pdc.org/APNHVA/kickoff.html

Policy Studies Institute - Environmental Group, University of Westminster http://www.psi.org.uk/

- Deliberative Mapping: http://www.psi.org.uk/research/project.asp?project_id=9

RAND Corp. Science and Technology Policy Institute http://www.rand.org/scitech/stpi/ 
Science and Policy Program, American Geophysical Union

http://www.agu.org/sci_soc/policy/

Science and Technology Directorate, Department of Homeland Security

http://www.dhs.gov/dhspublic/display?theme $=53$

Scottish Universities Policy Research and Advice Network, http://www.supra.ed.ac.uk/index.html

Stockholm Environmental Institute, University of York

http://www.york.ac.uk/inst/sei/welcome.html

Sustainability Research Institute, School of Earth and Environment, University of Leeds

http://www.env.leeds.ac.uk/research/sri/index.htm/

Tyndall Center for Climate Change Research, University of East Anglia

http://www.tyndall.ac.uk/

U.K. Climate Impacts Program, Department for Environment, Food \& Rural Affairs, University of Oxford http://www.ukcip.org.uk/

- Adaptation Wizard and Scenarios Gateway: http://www.ukcip.org.uk/resources/tools/

U.K. Engineering and Physical Sciences Research Council

http://www.epsrc.ac.uk/WebSite/

- Public Engagement Programme:

http://www.epsrc.ac.uk/WebSite/default.aspx?ZoneID =5\&MenuID $=118$

U.K. Office of Science and Technology

http://www.ost.gov.uk/

- Guidelines: http://www.orst.gov/uk/society/index.htm/

- Public Engagement with Science and Technology:

http://www.dti.gov/uk/ost/ostbusiness/puset/puset.htm/

Woodrow Wilson International Center for Scholars, Smithsonian Institution

http://wwics.si.edu 


\section{Appendix B. Summaries of Individual Organizations}

On the following pages are summaries of the individual organizations. The information listed for each organization was derived and summarized from their Web sites, as they appeared in the summer of 2004. Efforts cited in Appendix B should be considered not as "best practices" but as a summary of interesting efforts to be investigated further as the USGS Science Impact Program develops. Information provided for each organization includes:

- Name

- Parent organization (e.g., the university where a research group resides)

- Regulatory power (i.e., yes or no)

- Vision/mission statement: Text is taken directly from organization Web sites. I take no responsibility for the text provided here.

- $\quad$ Research theme

- Products

- Primary customers

- Additional notes 
Organization American Society of Limnology and Oceanography - Public Policy Activities

Parent Organization American Society of Limnology and Oceanography (ASLO)

Regulatory Power None

Vision/Mission None listed

Research Themes Aquatic sciences

Products

Information Web sites, updates on policy news in U.S. and Canada; links to policy Web sites

Primary Customers

ASLO scientists and members

Additional Notes

Web site provides public policy background for scientists (authorization vs. appropriations, how a bill becomes a law). It lists relevant laws for fisheries and limnology and information on how scientists can get involved in public policy. The Web site mentions the AAAS publication - "Working with Congress: A Practical Guide for Scientists and Engineers,” 2nd edition, by Williams Wells, Jr.

URL: http://aslo.org/policy/aslo.html 
Organization Annenberg School for Communication

Parent Organization University of Pennsylvania

Regulatory Power None

Vision/Mission Established in 1994, the Annenberg Public Policy Center of the University of Pennsylvania conducts and disseminates research, hosts lectures and conferences, and convenes roundtable discussions that highlight important questions about the intersection of media, communication, and public policy. The Policy Center, which has offices in Philadelphia and Washington DC, conducts ongoing research in the areas of political communication, information and society, media and the developing child, health communication and adolescent risk. Its research helps to bring difficult problems into focus.

Research Themes

Risk communication

Products

Publications: The Communicator (quarterly), Conference, science communication courses

Primary Customers public, scientists, journalists

Additional Notes This research group collaborates with the Centers for Disease Control and Prevention on communicating risks and research related to human health

URL: http://www.asc.upenn.edu/ 
Organization Australian Bureau of Rural Sciences (BRS)

Parent Organization Australia Department of Agriculture, Fisheries, and Forestry

Regulatory Power None

Vision/Mission The BRS provides scientific advice to government in support of more profitable, competitive and sustainable Australian agricultural, food, fisheries and forestry industries and enhancing the natural resource base to achieve greater national wealth and stronger rural and regional communities.

Research Themes Climate, Data, Fish, Forest, Landscape, Rural, Social Science,water, ag, forestry research

Products

Tools, publications, a FAQ for decision makers

Primary Customers

Decision makers and policy makers

Additional Notes

The Bureau of Rural Sciences is an independent scientific bureau within the Department of Agriculture, Fisheries and Forestry - Australia (AFFA). It is at the interface between science and policy and is considered an essential part of the Government's capacity for integrated evidence-based policy development

URL: http://www.affa.gov.au/brs 
Organization Board on Science, Technology and Economic Policy

Parent Organization National Academy of Sciences

Regulatory Power None

Vision/Mission From the organization's Web site: "To integrate understanding of scientific, technological, and economic elements in the formulation of national policies affecting the economic well-being of the United States."

Research Themes Macroeconomic and microeconomic variables and their relationship to U.S. science and technology

Products $\quad$ Newsletter, monographs, white papers, conferences, workshops and seminars

Primary Customers Policymakers responsible for trade, economic, science, and technology policy in the Executive Branch and Congress

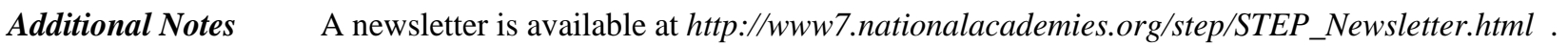
A current project relevant to the Science Impact Program is "Government-Industry

Partnerships for the Development of New Technologies."

URL: http://www7.nationalacademies.org/step/index.html 
Organization Center for Earth and Planetary Studies

Parent Organization Collections and Research Department of the National Air and Space Museum, Smithsonian Institution

\section{Regulatory Power None}

Vision/Mission

The Center for Earth and Planetary Studies (CEPS) conducts an active research program in planetary and terrestrial geology and geophysics using remote sensing data from Earth-orbiting satellites and manned and unmanned space missions. CEPS has curatorial responsibility for two museum exhibit galleries.

Research Themes

Products

Primary Customers

Additional Notes
Astrogeology

Publications; museum exhibits

General public

The Center for Earth and Planetary Studies (CEPS) is the scientific research unit within the Collections and Research Department of the National Air and Space Museum, Smithsonian Institution. The CEPS performs research and outreach activities on topics covering planetary science, terrestrial geophysics, and the remote sensing of environmental change. The group is an example of a research group fused with a museum so outreach on research results has a natural conduit to the public.

URL: http://www.nasm.si.edu/research/ceps/ 
Organization Center for Environment and Planning

Parent Organization University of the West England

Regulatory Power None

Vision/Mission The Centre for Environment and Planning promotes research on spatial planning, environmental management, land use, property, architecture and urban design. Our aim is to understand how policy and action can achieve high quality sustainable and equitable patterns of urban growth from the global to local scales.

Research Themes Interdisciplinary education on comparative and transnational planning, and Sustainable neighborhoods

Products publications, seminars, courses

Primary Customers Academia, professional planners

Additional Notes Project themes are sustainable urban and environmental management.

URL: http://www.built-environment.uwe.ac.uk/research/cep/ 
Organization Center for Environmental Research and Training

Parent Organization University of Birmingham

Regulatory Power None

Vision/Mission The center offers a broad spectrum of multi-disciplinary research expertise, provides a focus for the University of Birmingham's extensive environmental activities and acts as a gateway for external organizations [sic] enabling this expertise to be made more widely accessible.

Research Themes

Research, Industry, Information Resource, Training

Products

Information resource, courses (undergraduate, graduate, and professional), industry advisory, research

Primary Customers

Additional Notes
Students, Researchers, decision-makers

Research focuses on risk communication and Rural Economy and Land Use Program (RELU). RELU focus is to enhance the impact of research on rural policy and practice by involving stakeholders in all stages of RELU, including program development, research activities and communication of outcomes. The RELU Strategic Advisory Committee has identified four interdisciplinary themes as the core areas of research for the Program to address:

1. Integrated solutions for land and water resource use and management

2. The environmental basis of rural economies and regeneration

3. Successful and sustainable food products and food chains

4. Economic and social interactions with the rural environment

URL: http://www.cert.bham.ac.uk/ 
Organization Center for Health Policy Law and Management

Parent Organization Duke University

Regulatory Power No

Vision/Mission The Center's mission is to 1) stimulate and facilitate collaborative, interdisciplinary research by faculty and students at Duke University in health policy, drawing in particular on expertise in the social sciences, law, and management, 2) disseminate research findings on health policy to persons who make health policy decisions, and 3) provide a rich array of educational opportunities for undergraduate and graduate students seeking careers in health policy making, research and analysis

Research Themes Health Policy, Law and Management, Health inequalities

Products Research and education

Primary Customers Academia

Additional Notes This center emphasizes social science, law and management. The center focuses on research and education surrounding public health policy and management.

URL: http://www.hpolicy.duke.edu/ 
Organization Center for International Science and Technology Policy

Parent Organization Elliott School of International Affairs, George Washington University

Regulatory Power None

Vision/Mission The Center for International Science and Technology Policy (CISTP), which is part of George Washington University's Elliott School of International Affairs, is one of the University's focal point for these activities. The Center manages GW's Master of Arts program in International Science and Technology Policy, formerly called the Master of Arts program in Science, Technology, and Public Policy, as well as provides a field of study for doctoral and master's degree candidates from other parts of the University. The Center also carries out research projects for a variety of government and non-government sponsors, organizes seminars and symposia on significant science and technology issues, and hosts visitors from other parts of the United States and overseas.

Research Themes

Space policy, innovation policy

Products

Primary Customers

Additional Notes

\section{Articles}

Federal Government

CISTP has three major areas of research. The Space Policy Institute concentrates its research and teaching efforts on issues related to the world's space programs. Substantial research is also underway on innovation policy, specifically the policy implications of technological innovation as it is carried out by firms and other organizations. New theories, such as the sciences of complexity and national innovation systems are examined for their relevance to innovation policy-making. Faculty are also involved in research on technology and industry dynamics where particular emphasis of recent work has been on scientific and technological cooperation and competition. This research includes a focus on the economic analysis of technological change triggered by cooperation among firms and other actors (e.g., universities, government agencies).

URL: $h t t p: / / w w w . g w u . e d u / \sim c i s t p$ 
Organization Centre for Research into Innovation, Culture, and Technology

Parent Organization Brunel University, West London

Regulatory Power None

Vision/Mission CRICT carries out research into the social and cultural dimensions of science and technology, with a particular focus on the dynamic relations between new technologies, new knowledge and social, cultural and organizational change. We aim to enrich understanding of these issues by drawing on a wide range of perspectives and styles from across the social sciences and humanities, and to use the insights gained from this research to contribute to topical debates in both academic and policy arenas.

Research Themes Technology and sociality, Knowledge and expertise, (Understanding of) Risk, controversy and ethics, Medicine, Technology and the Body

Products

Professional papers, courses, degrees

Primary Customers

Academia

Additional Notes

CRICT research focuses on qualitative sociological and historical research, employing approaches such as ethnography, discourse analysis and conversation analysis. Projects involve direct observation, interviews, and the collection of original documents, and would very rarely involve surveys or other large-scale data collection. An area of research is the application of conversation analysis to computer-mediated communication and in the development of ethnographic approaches to understanding the Internet.

URL: http://www.brunel.ac.uk/depts/crict/ 
Organization Center for Science and Technology Policy Research

Parent Organization Cooperative Institute for Research in Environmental Sciences, UC Boulder

Regulatory Power

Vision/Mission

Research Themes

Products

Primary Customers

Additional Notes
None

The Center conducts research, education, and outreach to improve the relationship between societal needs and science and technology policy

Research, Outreach and Education surrounding 3 main themes...see notes below.

Hydro-Climate research and decision making, Outdoor Classroom, Science and Technology, Western Water Assessment

Academia, decisionmakers

Main Themes are 1) Evaluating the relationship between societal needs and science and technology policies, 2) Providing new policy alternatives for science and technology policy decision makers, and 3) Developing tools for science and technology policy decision making. Example projects include the evaluation of the effectiveness of drought-related watering restrictions in Colorado's Front Range during the 2002 drought, efforts to identify and characterize regional vulnerabilities to climate variability and change and efforts to create "Information Brokers." Center staff are developing tools for improving linkages between carbon cycle science and management decisions that may involve considerations of carbon cycle science, based on the relations between evolving scientific and technological opportunity, political reality, and demand-side capability. Center staff are working with the Colorado Basin River Forecast Center to compare our experimental stream-flow forecasting procedures with the current operational procedures during the 2003 snow melt season, and are also working with the NWS Office of Hydrologic Development to infuse our experimental forecasting techniques in the NWS Advanced Hydrologic Prediction System.

Publications of note:

Anderson-Berry, L., T. Keenan, J. Bally, R. A. Pielke, Jr., R. Leigh, and D. King, 2004. The Societal, Social, and Economic Impacts of the World Weather Research Programme Sydney 2000 Forecast Demonstration Project (WWRP S2000 FDP), Weather and Forecasting, Volume 19, pp. 168-178.

Pielke, Jr., R. A. 2004 (in press). Abortion, Tornadoes and Forests: Thinking about Science, Politics and Policy, Chapter in J. Bowersox and K. Arabas (eds.) Forest Futures: Science, Policy and Politics for the Next Century (Rowman and Littlefield).

Stewart, T. S., R. A. Pielke, Jr., and R. Nath, 2004: Understanding User Decision Making and the Value of Improved Precipitation Forecasts: Lessons from a Case Study, Bulletin of the American Meteorological Society, Vol. 85, No. 2, pp. 223-235.

URL: http://sciencepolicy.colorado.edu/ 
Organization Center for Science, Technology, and Congress

Parent Organization American Association for the Advancement of Science

Regulatory Power None

Vision/Mission To provide timely, objective information to Congress on current science and technology issues and assists the science and engineering community in understanding and working with Congress.

Research Themes Human cloning, stem cell research, energy policy, human research subject protections, public access to research data

Products Policy briefs, newsletter, online archive, research funding

Primary Customers Congress

Additional Notes Funded by a grant from the Burroughs-Wellcome Fund, the group was established in 1994 and publishes the monthly newsletter "Science and Technology in Congress."

URL: http://www.aaas.org/spp/cstc/ 
Organization Coastal Services Center

Parent Organization National Oceanic and Atmospheric Administration

Regulatory Power None

Vision/Mission The mission of the NOAA Coastal Services Center is to support the environmental, social, and economic well being of the coast by linking people, information, and technology.

Research Themes

Technology Applications for smart growth, habitat, hazards, National Spatial Data Infrastructure (NSDI), Organization and culture

Products

Primary Customers

Additional Notes
Training, Solutions, Fellowships, Funding, On-line Mapping, Data \& Standards, Tools \& Extensions, publications, library

Local and state coastal resource and hazard mitigation managers

Strategic plan is available. Main office in Charleston, South Carolina serves CONUS; Pacific Services Center serves Hawaii and Pacific Islands. The NOAA CSC has the following programs:

1. Coastal Learning Center: Professional technical and managerial training for land-use, hazard, and resource managers of the coast.

2. Coastal Remote Sensing: Remote sensing data products, tools and training.

3. GIS Integration and Development: data access and distribution, Internet mapping, and spatial data analysis and visualization as a means of addressing coastal hazards, smart growth, marine protected areas, or coastal permitting issues.

4. Landscape Characterization and Restoration: explores the interrelationships of a region's ecology, land use, socioeconomics, and management, and publishes this information in electronic format for use by the coastal management community. The program works via grants, cooperative agreements, and contracts with coastal programs to accomplish its goals. 5. Outreach: Facilitates communication among local, state, and federal coastal resource management programs.

6. Pacific Services Center: develops and delivers coastal management information and services to the State of Hawai i, Territories of American Samoa and Guam, and the Commonwealth of the Northern Mariana Islands. Staff includes director, coastal hazards specialist, training and outreach coordinator, spatial technology coordinator, geospatial technician, management and program analyst, and coastal program coordinator.

URL: www.csc.noaa.gov 
Organization Consortium for Science, Policy \& Outcomes

Parent Organization Arizona State University

Regulatory Power None

Vision/Mission The Consortium for Science, Policy, and Outcomes is an intellectual network aimed at enhancing the contribution of science and technology to society's pursuit of equality, justice, freedom, and overall quality of life. The Consortium creates knowledge and methods, cultivates public discourse, and fosters policies to help decision makers and institutions grapple with the immense power and importance of science and technology as society charts a course for the future.

Research Themes Choosing between different types of research; match knowledge creation with knowledge needs; enhancing the benefits of new knowledge and innovation

Products research articles, books, mention of outreach and education (academia related)

\section{Primary Customers Academia}

Additional Notes

A 20-yr plan is available. Project sub-themes include New Science Policy, Living with the Genie*, Societal Outcomes Map for Health Research, Understanding the Uneven Advance of Knowledge, Extracting Societal Benefit from Earth Systems Research, Prediction in Public Policy, An Outcome-Based Extreme Events Research Agenda, Nanotechnology and Society, Basic Research in Service of Public Objectives, Science and Public Value, and Distributional Impacts of Science and Technology Policies. Information of Public Value Mapping and Public Failure research is available.

Article example: Agrawala, Shardul, Kenneth Broad, and David H. Guston. In press.

"Challenges to an Emergent Boundary Organization: Integrating Climate Forecasts and Societal Decision Making." Science, Technology \& Human Values 26(3).

URL: http://www.cspo.org/ 
Organization Cooperative Ecosystems Studies Unit

Parent Organization none

Regulatory Power None

Vision/Mission The objectives of this network are to:

- provide resource managers with high-quality scientific research, technical assistance, and education;

- deliver research and technical assistance that is timely, relevant to resource managers, and needed to develop and implement sound adaptive management approaches;

- ensure the independence and objectivity of research;

- create and maintain effective partnerships among federal agencies and universities to share resources and expertise;

- take full advantage of university resources while benefiting faculty and students;

- encourage professional development of federal scientists; and

- manage federal science resources efficiently.

Research Themes

Products

Primary Customers

Additional Notes
Biological, physical, social, and cultural studies

Research, technical assistance, education

Academia, federal agencies

Key elements of each CESU include: 1) multiple federal agencies, 2) a host university, 3) partner institutions, 4) a role and mission statement, 5) a managers committee, and 6) strategic and annual work plans. CESUs are based at universities and focused on a biogeographic region of the country. Universities provide space, basic administrative support (secretarial, accounting, equipment), and access to university faculty, students, staff, and resources. Federal agencies contribute research scientists and/or other professionals. In many cases, these federal personnel are located and working at CESUs under formal agreements between their respective bureaus and universities. Federal personnel are supervised and supported by their respective agencies, through existing administrative systems. Participating agencies provide scientific staff, administrative support funds (for assistance beyond the basic support provided by the universities), and project funds for specific research projects and technical assistance. Federal agency participation in a CESU does not alter previous arrangements or cooperative agreements. CESUs will create additional opportunities for interdisciplinary and multi-agency research, technical assistance, and education.

URL: http://www.cesu.org/cesu/index.html 
Organization Cooperative Institute for Coastal and Estuarine Environmental Technology

Parent Organization NOAA and UNH

Regulatory Power None

Vision/Mission CICEET was established as a partnership between the National Oceanic Atmospheric Administration (NOAA) and the University of New Hampshire (UNH) in 1997 and is located on the UNH campus in Durham, NH. CICEET uses the capabilities of UNH, the private sector, academic and public research institutions throughout the U.S., as well as the 26 reserves in the National Estuarine Research Reserve System (NERRS), to develop and apply new environmental technologies and techniques.

Research Themes Toxic contaminants, microbial contaminants, nutrient over-enrichment, habitat loss/restoration, data synthesis/integration

Products

Reports, tools

Primary Customers

Coastal resource managers

Additional Notes

This organization has a good project explorer tool. The group funds researchers to develop applications and tools for coastal resource managers. There are many projects to look at as examples of applied research and technology development

URL: http://www.ciceet.unh.edu/index_flash.html 
Organization

Parent Organization

Regulatory Power

Vision/Mission

Research Themes

Products

Primary Customers

Additional Notes
Council for Excellence in Government

nonpartisan, nonprofit organization

None

--To attract and develop talented people for public service;

--To encourage innovation and results-oriented performance in government;

--To promote e-government as a revolutionary tool for improving performance and better connecting people to government; and

--To improve the connection between citizens and government and encourage their participation in governance.

Greater interaction with government and the public; e-government; homeland security

White papers, books, newsletters

General public

The Council is designed to generate better impact of federal activities in general. From organization's Web site: Pursuing its mission to improve the performance of government and the connections between government and citizens, it focuses its strategic priorities in four areas--to attract and develop the best and brightest for public service; encourage innovation and results-oriented government performance; engage citizens in government; and promote electronic government as a resource to achieve all of these goals. The Council's 700 members, or Principals, are business, education and nonprofit leaders who have served in government. A volunteer chair and board of trustees lead the organization, working with the president and CEO and Council staff. Former Presidents Ford, Carter, Bush, and Clinton serve as honorary co-chairs.

Relevant publications:

- "Linking resources to results": http://excelgov.org/displayContent.asp?NewsItemID=3976\&Keyword=ppStudies

- "Ethical Principles for Public Servants": http://excelgov.org/displayMainSection1.asp?keyword=ppStudies

URL: http://excelgov.org/ 
Organization Council of Scientific Society Presidents

Parent Organization none

Regulatory Power No

Vision/Mission The Council of Scientific Society Presidents is an organization of presidents, presidents-elect, and recent past presidents of about sixty scientific federations and societies whose combined membership numbers well over 1.4 million scientists and science educators. Since 1973 CSSP has served as a strong national voice in fostering wise science policy, in support of science and science education, as the premier national science leadership development center, and as a forum for open, substantive exchanges on emerging scientific issues

Research Themes Population and Environment; Science and Math Education; Government and Public Affairs, Ethics in Science, Public Understanding of Science, International Activity

Products annual forums, policy statements

Primary Customers Government, academia, and industry

Additional Notes

URL: http://www.cssp.us/ 
Organization

\section{Parent Organization}

Regulatory Power

Vision/Mission

Research Themes

Products

Primary Customers

Additional Notes
Department of Environmental Policy and Management Group

Imperial College London

None

From organization's Web site: To contribute to the analysis and development of effective environmental policies and management in situations where scientific understanding and technological innovation play a major role. Imperial College embodies and delivers world class scholarship, education and research in science, engineering and medicine, with particular regard to their application in industry, commerce and healthcare. We foster interdisciplinary working internally and collaborate widely externally.

Energy Policy and Tech, Environmental Assessment and Mgmt, Environmental Economics, Society and Policy, Environmental Law

Research articles and education

Academia

The Web site is a gateway to a number of papers on science, technology and policy (many of which have to do with economics). EPMG focuses on researching policy effect on society, economic, and the landscape. The focus uses environmental science to compare alternative policies to future economic, political and environmental settings.

URL: http://www.iccept.ic.ac.uk/public.html 
Organization Division of Economics

Parent Organization U.S. Fish and Wildlife

Regulatory Power Yes

Vision/Mission To provide technical assistance in support of the Service's mission. Both short term/quickturnaround staff support and longer term assistance for economic and policy analyses will be provided to the Washington, Regional and field station offices.

Research Themes Economic impact of resource management

Products Reports

Primary Customers US Fish and Wildlife offices

Additional Notes In-house capabilities and experience include:

- Economic impact analyses for critical habitat designation,

- Economic analysis of natural resource damages,

- Economic methodology development,

- Policy analyses, Record of Compliance statements,

- Assistance with legislative packages and reviews,

- General economic analysis assistance.

URL: http://economics.fws.gov/ 


\section{Organization}

Parent Organization

Regulatory Power

Vision/Mission

Research Themes

Products

Primary Customers

Additional Notes
Earth Science Applications

National Aeronautics and Space Administration (NASA) Earth Science Enterprise

None

To optimize benefits from NASA's Earth Science investments through systems engineering to advance decision support tools that serve the nation. To provide societal benefits through application of ESE research and technology.

Agricultural Efficiency, Air Quality, Aviation, Invasive Species, Carbon Management, Coastal Management, Disaster Management

Interactive maps, downloadable data, regional studies, decision support tools

Public and private sector

The Earth Science Applications theme of the NASA, conducted within the Earth Science Enterprise (ESE), benchmarks practical uses of NASA-sponsored observations from Earth observation systems and predictions from Earth science models. NASA implements projects that carry forth this mission through partnerships with public, private, and academic organizations. These partnerships focus on innovative approaches for using Earth science information to provide decision support that can be adapted in applications worldwide. The ESE program focuses on applications of national priority to expand and accelerate the use of knowledge, science, and technologies resulting from the ESE goal of improving predictions in the areas of weather, climate, and natural hazards. The approach is to enable the assimilation of Earth Science model and remote sensing mission outputs to serve as inputs to decision support tools in integrated system solutions. The Earth Science Applications Directorate includes:

1. The Applications Research Division develops and enhances Earth Science products for the advancement of earth system science and its application to societal concerns.

2. The Engineering Division develops advanced tools to enhance the performance and the results of Earth observation missions.

3. The Integrations Division works with the Research and Engineering Divisions to represent the program to outside interests while also performing functions that ensure smooth coordination and integration within NASA and Stennis Space Center.

Documents: 1) Science for Society-Benchmarking the use of Earth System Science Results for Decision Support.doc, 2) Online Journal:

http://satjournal.tcom.ohiou.edu/Issue03/science_society.html

News articles related to ESAD: http://www.esad.ssc.nasa.gov/news.aspx

Affiliated Research Centers with four universities to do remote sensing applications:

http://www.esad.ssc.nasa.gov/arc/default.aspx?s=6

Small Business Innovation Research - (SBIR):

http://www.esad.ssc.nasa.gov/program.aspx?p=SBIR

Regional Earth Science Application Centers (RESAC): seven universities given money to conduct research on applied issues, check:

http://www.esad.ssc.nasa.gov/program.aspx?p=RESAC\&s=1

URL: http://www.earth.nasa.gov/eseapps/index.html 
Organization

\section{Parent Organization}

Regulatory Power

Vision/Mission

Research Themes

Products

Primary Customers

Additional Notes
Enterprise Development Impact Assessment Information Service

Department for International Development, University of Manchester

None

Enterprise Development Department has identified the need for a central resource which can advise regional and country-based Enterprise Development Advisers (EDAs) on 'good practice,' design and methods of impact assessment (IA). In this context EDIAIS will aim to provide information and expertise in enterprise development impact assessment to DFID and the wider development community.

poverty impact assessments, participatory strategies, methodology information dissemination

Applied Impact Assessments, Dissemination on Impact Assessment Methodologies and results, tools, resources

Countries and regions of poverty

Many of EDIAIS products involve the dissemination of "how-to" guides for conducting impact assessments.

URL: www.enterprise-impact.org.uk 
Organization

Parent Organization

Regulatory Power

Vision/Mission

Research Themes

Products

Primary Customers

Additional Notes
Environmental and Societal Impacts Group

The National Center For Atmospheric Research, University Corporation for Atmospheric Research

None

To integrate societal needs with knowledge of the environment to better understand and communicate impacts of weather, climate, and global change. ESIG fosters cross-disciplinary research by bridging social and natural sciences, the humanities, and technology to inform decision-making.

Research, Publications, Workshops, and Outreach

Publications, GIS, Workshops, Outreach programs, online newsletter

Public, academia, federal regulatory commissions

Research Themes include 1) The Science of Weather and Climate Impact Assessment; 2) Use and Value of Weather and Climate Information for Decision Making; 3) Education,

Informatics, and Communications. Outreach Themes inclue 1) International Outreach, 2)

Collaborations within the Science Community, 3) Educational Outreach, 4) Community

Service, 5) Online Newsletters. Research projects of note for USGS researchers include:

- NCAR Geographic Information System (GIS) Strategic Initiative (www.gis.ucar.edu)

- Wildland Fire Research and Development Collaboratory

(www.wildlandfirecollaboratory.org)

- Economic Value of Weather and Climate Forecasts (www.esig.ucar.edu/HP_rick/esig.html)

- International Fisheries and Climate Variability (www.esig.ucar.edu/fisheries/)

- Weather Information Needs (no Web site available)

- Assessing the Needs of Users of Quantitative Precipitation Forecasts (no Web site available)

- Climate Variability and Uncertainty in Flood Hazard Planning in Colorado

(www.assessment.ucar.edu/flood/)

- Ethics of Development and Use of Weather and Climate Forecasts (no Web site available)

- Societal and Economic Impact Subprogram of THORPEX: A Global Atmospheric Research

Programme (www.mmm.ucar.edu/uswrp/programs/thorpex.html)

- The Economics of Climate Variability and Global Change (CLIM-ECON)

(www.atd.ucar.edu/mailman/listinfo/clim-econ/)

- Supply and Demand of Carbon Cycle Information (no Web site available)

- Use of Information during the Pacific Land-Falling Jets Experiment: The Pacific Landfalling

Jets Experiment 2001 (PACJET-2001)

URL: http://www.esig.ucar.edu/ 
Organization

Parent Organization

Regulatory Power

Vision/Mission

Research Themes

Products

Primary Customers

Additional Notes
EPA Science Policy Council

U.S. Environmental Protection Agency

Yes

The Office of the Science Advisor (OSA) provides leadership in establishing specific mechanisms for ensuring that scientific results and hypotheses, with technical evaluation and peer-review, play a prominent role in all regulatory decisions. These efforts will help ensure regulations are interpreted and enforced in a manner consistent with the science supporting them and will strengthen EPA's overall scientific performance.

Resource management; environmental quality

Policies

State and local resource managers; private industry

There is Information on their Web site about:

1. The Science Policy Council (SPC) is chaired by the Science Advisor. The SPC is an important cross agency group of senior managers that focuses on major science policy issues and approves positions for the Agency, such as peer review, risk assessment and risk characterization, genomics, and regulatory environmental modeling.

2. The Office of the Science Advisor

3. Role and Use of Science at EPA

4. The Science Advisor's role in the World Trade Center Review Panel

Information about the Science Policy Council

The Science Policy Council (SPC) was established in 1993 under Administrator Carol Browner with a broader mission and a new Framework as a replacement to the RAC. With a goal of integrating policies that guide Agency decision-makers in their use of scientific and technical information, the SPC works to implement and ensure the success of selected initiatives recommended by external advisory bodies such as the National Research Council and the Science Advisory Board, as well as others such as the Congress, industry and environmental groups, and Agency staff. In this way, the SPC provides guidance for selected EPA regulatory enforcement policies and decisions.

As part of EPA Administrator's initiative to improve the Agency's policy-making process to better integrate the highest quality science, she created the position of Science Advisor to the Agency. One of the duties of the Science Advisor is to assume the chair of the Science Policy Council. The SPC continues to be supported by standing groups such as the Risk Assessment Forum, a Steering Committee, and by interim working groups. A small staff positioned in the Office of Science Advisor supports the SPC and its Steering Committee.

URL: http://www.epa.gov/osa 
Organization

\section{Parent Organization}

Regulatory Power

Vision/Mission

Research Themes

Products

Primary Customers

Additional Notes
European Commission's Science and Society theme

European Commission

None

Advances in science drive European growth, but sometimes give rise to fears and scepticism among citizens. The European Commission is determined to bridge the gap between the scientific community and society at large. The "Science and Society" theme within the European Research Area supports activities that bring together policy-makers, researchers, and citizens. In this section, you will learn about the Commission's efforts to take science out of the lab and into the public arena

General science

Guideline documents, Science Shops,

EU citizens, scientists

Organizational model available. Relevant points for Science Impact include:

1. Guidelines on 1) involving citizens in science 2) guidelines for scientists, and 3) reports on public participation

2. SINAPSE - Scientific INformAtion for Policy Support in Europe - tool kit for the practical implementation of new forms of governance, facilitating the involvement of actors who are currently hard to consult, and enabling them to share their knowledge and viewpoints.

SINAPSE will be freely accessible at http://europa.eu.int/sinapse. The pilot phase should start in summer 2004 and the membership will then be extended progressively. Tools include Who's Who and Yellow Pages for scientific and policy expertise, library of scientific opinions and advice, EC consultation, early warning system, provides communication between members. URL: http://europa.eu.int/comm/research/science-society/documents_en.html 
Organization

Federation of Earth Science Information Partners

Parent Organization None

Regulatory Power

Vision/Mission

Research Themes

Products

Primary Customers

Additional Notes

None

Links to data sources and science information

Education, Science Users
The goal of the ESIP Federation is to establish and continuously improve science-based endto-end processes that increase the quality and value of Earth science products and services throughout their life-cycle for the benefit of the ESIP Federation's stakeholder communities

Data-Research, Data-Applications, Education Resources, Technology and Tools

The main purpose is to make science data more accessible through partnerships with public and private sectors. It is more of a clearinghouse for education materials (k-12) and data products. Partners are organized as:

1. Type I: primarily distributors of satellite and ground-based data sets, as well as standardized products derived from those data; includes Alaska Satellite Facility, EROS Data Center, Global Hydrology Resource Center, Goddard Space Flight Center, Jet Propulsion Laboratory, Langley research Center, Natinoal Climate Data Center, national Oceanographic Data Center, National Snow and Ice Data Center, Oak Ridge National Laboratory, Socioeconomic Data and Applications Center.

2. Type II: provide data and information products, technology, or services aimed primarily at the Earth science and research communities.

3. Type III: primarily commercial companies engaged in developing tools for Earth Science.

URL: http://www.esipfed.org/ 


\section{Organization}

\section{Parent Organization}

Regulatory Power

Vision/Mission

Research Themes

Products

Primary Customers

Additional Notes
Focused Science Delivery Program

\section{U.S. Forest Service}

\section{Yes}

The mission of the Focused Science Delivery (FSD) Program is to strengthen natural resource policy and decisionmaking processes by developing and communicating science products that synthesize and integrate existing information within or across disciplinary areas at appropriate spatial and temporal scales.

Data-Research, Data-Applications, Education Resources, Technology and Tools

Research, development, and application program

Science Users, policymakers

The Focused Science Delivery Program is a research, development, and application program that works across all four of the PNW Station strategic goals by conducting analyses of existing scientific data and compilations of existing information to create new knowledge. The FSD program also works more broadly on west-wide (Forest Service Regions 1-6 and 10) and national issues when they are consistent with the PNW Research Station's mission, or when they rise to the level that they become important in the PNW region.

The Program's work supports high priority policy and management analyses and identifies knowledge gaps that require collection of new data to support more complete analyses. The FSD program is unique among the PNW Station's research programs because it does not maintain a large permanent staff, yet its mandate covers the range of topics about which the Forest Service conducts original research. In many cases the program secures the analytical capability necessary to accomplish work by developing partnerships among the PNW Station's other research programs, with Forest Service Research Projects or Programs from other Research Stations, or with government and non-government organizations where individuals with the necessary skills are located. Program staff members hold regular discussions with policy makers and managers at all organizational levels to identify topics for investigation and to tailor outputs to clients' or users' needs. This process is both informal and formal, with formal discussions held biennially in odd numbered years to select upcoming topics for the FSD Program.

The topics addressed rotate in and out of the program, each with a lifespan of generally 2-3 years in duration. The FSD program promotes integration with an emphasis on the Forest Service's strategic needs and identifies ways to increase synergy among researchers, political leaders, management experts, and the public as they search for solutions to complex resource management problems. We conduct analyses of existing scientific information and package results to support formulation of policy, selection of the management actions that implement those policies, and to provide scientifically sound information to the public as they help to shape policy or influence management decisions. As a result, most of the program's work responds to Goal 4 of the PNW Station's Strategic Plan (Communicate science findings and enhance their application). The changing nature of the program's portfolio of work does, however, make it likely that the various analyses conducted by the FSD program will touch on all of the PNW Station's strategic goals and priorities.

URL: http://www.fs.fed.us/pnw/about/programs/fsd/ 
Organization

Parent Organization

Regulatory Power

Vision/Mission

Research Themes

Products

Primary Customers

Additional Notes
Government Affairs Program

American Geological Institute

\section{No}

The AGI Government Affairs Program (GAP), established in 1992, serves as an important link between the federal government and the geosciences community. Through Congressional workshops, testimony, letters, and meetings, GAP ensures that the voices of the AGI Member Societies are heard on Capitol Hill and in the executive branch. At the same time, GAP is working to improve the flow of geosciences information to policy-makers. Equally important is the program's mission of providing federal science-policy information back to the Member Societies and the geosciences community at large.

Geosciences

GeoRef (bibliographic database); Geotimes (monthly magazine); scholarships, information services

Federal government and geosciences community

URL: http://www.agiweb.org/gap/ 
Organization

Parent Organization

Regulatory Power

Vision/Mission

Research Themes

Products

Primary Customers

Additional Notes
Science Translation Project

Gulf of Maine Council on the Marine Environment

None

Initiated in 2002, the Gulf of Maine Council's Science Translation Project accelerates the transfer of scientific findings and techniques to resource managers, planners, policy makers, and other coastal decision-makers in the region.

Science translation

Project coordination and facilitation

Local decision-makers

The vision for the Science Translation Project is that government officials at the state, provincial, and federal levels will have an accurate, up-to-date scientific understanding of key environmental issues to make informed decisions on management of the Gulf of Maine and its watershed. The goal of the Gulf of Maine Council's Science Translation Project is to advance science-based management of the Gulf of Maine and its watershed by equipping state, provincial, and federal decision-makers with scientific information. The context for this initiative is the Council's priorities as described in its Action Plan 2001-2006. Objectives include:

- Identify specific needs among state, provincial, and federal decision-makers for scientific information pertaining to coastal/marine habitats and contaminants.

- $\quad$ Produce innovative, targeted information materials and deliver them in formats (e.g., publications, workshops, Web-based resources) that are responsive to decision-makers' needs.

- Translate technical and scientific data into identifiable, meaningful management actions.

- Develop partnerships with other organizations that can fund and help multiply the impact of science translation efforts

- Continually evaluate the outcomes of science translation activities and adapt future activities to maximize success.

URL: http://www.gulfofmaine.org/science_translation/ 
Organization H. John Heinz III Center for Science, Economics and the Environment

Parent Organization Non-profit organization

Regulatory Power None

Vision/Mission Dedicated to improving the scientific and economic foundation for environmental policy through multi-sectoral collaboration. Focusing on issues that are likely to confront policy makers within two to five years, the Center creates and fosters collaboration among industry, environmental organizations, academia, and government in each of its program areas and projects.

Research Themes Environmental Reporting, Global Change, Sustainable Ocean, Coasts, and Waterways

Products Publications, policy recommendations

Primary Customers Policy makers, managers

Additional Notes

The group focuses on issues that are likely to confront policymakers. Within two to five years, the Center creates and fosters collaboration among industry, environmental organizations, academia, and government in each of its program areas and projects.

URL: http://www.heinzctr.org/ 
Organization Institute for Environment, Philosophy, and Public Policy (IEPPP)

\section{Parent Organization Lancaster University}

Regulatory Power None

Vision/ The Institute for Environment, Philosophy and Public Policy brings together academics from philosophy and the social sciences. IEPPP's overall research objective is to develop fresh cross-disciplinary thinking about the growing range of social and ethical issues thrown up by new technological developments.

Research Themes

Products

Primary Customers

Additional Notes
Agriculture and Environment Biotechnology, Human Genome Ethics, Science and Society

M.A and PhD in Environment and Society, degrees, basic research, publications,

Agriculture and Environment Biotechnology Commission, Animal Procedures Committee, the Food Ethics Council

The Center for the Study of Environmental Change's central concern is to explore and clarify the ways in which an adequate understanding of environmental issues is now being compromised by restrictive assumptions in both policy and academic cultures, with the result that implications of the far-reaching cultural tensions embedded in environmental critiques of modern society are being neglected. Journals published by the institute include: Bioethics, Environmental Values, and Worldviews: Environment, Culture, Religion. Example Report is "Grove-White, R, and B Wynne (1995), Science, Culture and the Environment (Research Report), Lancaster: IEPPP, Lancaster University. ”

URL: http://www.lancs.ac.uk/fss/ieppp/ 
Organization Macaulay Institute

Parent Organization Scottish Office of the UK Government

Regulatory Power None

Vision/Mission They undertake research that provides scope for:

1) Rural economic development and a viable rural community structure

2) The protection and enhancement of natural resources

Research Themes

Products

Primary Customers

Additional Notes
Commercial Services, Research,

Workshops/Conferences, GIS services, maps, datasets, Training, science info to advisory councils, Decision Support Tools,

UK government

Research carried out is an integrated study of the physical, environmental, and social consequences of land use, which is undertaken at various levels of physical, chemical, and biological organization and its outcome is invariably expressed with reference to location, spatial pattern and distribution. Research is aimed at meeting the needs of land managers and those formulating and implementing land use policy in the UK and Europe. A considerable part of their research program is concerned with the development of decision-support tools.

URL: http://www.mluri.sari.ac.uk/intro.htm 
Organization Marine Policy Center

Parent Organization Woods Hole Oceanographic Institution

Regulatory Power No

Vision/Mission The Marine Policy Center (MPC) conducts social scientific research to advance the conservation and management of marine and coastal resources. The work of MPC researchers integrates economics, policy analysis, and law with WHOI's basic strengths in the ocean sciences and engineering

Research Themes Marine resources; marine conservation; marine pollution

Products

Journal articles, conferences, fellowship program

Primary Customers

Public and private sector

Additional Notes

Most studies are on economic impact of various marine policy issues

URL: http://www.whoi.edu/science/MPC/dept/index.html 
Organization

\section{Parent Organization}

Regulatory Power

Vision/Mission

Research Themes

Products

Primary Customers

Additional Notes
MMS Environmental Sciences Program

Minerals Management Service (MMS)

Yes

Information archive

Environmental and socioeconomic research

Policy analysis, economic analysis, stakeholder needs assessments

Mineral Management Service

The Environmental Studies Program of the Mineral Management Services conducts issues identification studies related to oil and gas development in the Outer Continental Shelf. These studies include the identification of the various stakeholders, their issues and concerns towards the environment, risk analysis, opportunities for public involvement, areas of potential conflict and resolution, and significant issues for further research. The Environmental Sciences Branch (ESB) provides policy guidance and program direction and oversight for the MMS

Environmental Studies Program and the MMS Oil Spill Modeling Program. The ESB provides national level coordination with research managers within the Department of the Interior, other Federal agencies and coordinating committees, and non-federal research organizations. The ESB staff provides: 1) Management of the Environmental Studies Program and 2)

Management of the Oil Spill Modeling Program, as well as technical information and analyses for NEPA and OCSLA reports, and proposed legislation and regulations that may affect OCS activities. For information pertaining to operational safety, pollution prevention, oil spill response, and cleanup capabilities, visit our Technology Assessment and Research (TA\&R) Program. The TA\&R Program is a research element encompassed by the MMS Regulatory Program. It was established in the 1970's to ensure that industry operations on the Outer Continental Shelf incorporated the use of the Best Available and Safest Technologies (BAST) subsequently required through the 1978 OSCLA amendments.

URL: http://www.mms.gov/eppd/env/ 
Organization National Council for Science and the Environment

Parent Organization None

Regulatory Power None

Vision/Mission The Council mobilizes key communities, including Congress, government agencies, academia, civil society, business, media, and the public to support policies and programs that increase the role of science in achieving environmental goals. The Council informs these communities about the value of science as a basis for decisions that affect the environment.

Research Themes Increasing funding for research, assessment, and education

Products Conferences, newsletters, testimony, advocacy

Primary Customers Congress, D.C. policy makers

Additional Notes

Slogan is "Developing a scientific base for environmental decision making"

URL: http://www.ncseonline.org/ 
Organization Nature and Science Program

Parent Organization National Park Service

Regulatory Power Yes

Vision/Mission Manage and protect U.S. National Parks

Research Themes Outreach, opportunities for researchers

Products

Quarterly bulletin, research learning centers (13), Geoscientists-in-the-Parks, interpretative services, CESUs

Primary Customers General public

Additional Notes

Products and programs include:

Park Science Newsletter: http://www2.nature.nps.gov/parksci/

Research Learning Centers: http://www.nature.nps.gov/learningcenters/main_centers3.html Cooperative Ecosystem Studies Units:

http://www.cesu.org/cesu/introduction/introduction.html

The Social Science Program of the NPS can be found at

http://www.nature.nps.gov/socialscience/products.htm

URL: http://www.nature.nps.gov/scienceresearch/ 
Organization

\section{Parent Organization}

Regulatory Power

Vision/Mission

Research Themes

Products

Primary Customers

Additional Notes
National Science and Technology Center

Bureau of Land Management

Yes

BLM: The Bureau of Land Management (BLM), an agency within the U.S. Department of the Interior, administers 261 million surface acres of America's public lands, located primarily in 12 Western States. The BLM sustains the health, diversity, and productivity of the public lands for the use and enjoyment of present and future generations. The NSTC's focus is to provide science and technology related services to other Bureau offices. These services include:

- Providing synthesized information, including literature searches, pertaining to the most current science associated with a specific management or resource issue

- Assessing the synthesized information and providing insights into available data, data formats, and technologies

- Identifying current technologies or developing applications of technologies to meet management or resource needs

- Preparing short synopses of relevant scientific information in an easily understandable format

- Identifying and developing partnerships with organizations and institutions that can provide scientific services and expertise

\section{Conservation of BLM land}

GIS data, publications, annual reports

General public

A list of science products and the organizational framework is available at the Web site. An interesting study is the "Conversation with America"

(http://www.blm.gov/nhp/NPR/conversations/) which includes electronic conversations, customer surveys, public meetings, Resource Advisory Councils, and comment cards

URL: http://www.blm.gov/nstc/ 
Organization

Parent Organization

Regulatory Power

Vision/Mission

Research Themes

Products

Primary Customers

Additional Notes
National Visual Analytics Center (NVAC)

Pacific Northwest National Laboratory (PNNL)

None

The Center, led by Pacific Northwest National Laboratory (PNNL), is a national resource that provides strategic direction and coordination of activities to discover, develop and implement innovative visual information analysis methods.

Research and Development, Education, Evaluation and implementation, Integration

Visualization software to georeference paper trails and intelligence

Department of Homeland Security

Funding comes from Department of Homeland Security - Science and Technology Directorate. Research and Development activities include areas of information analysis and visualization with an emphasis on proactive, predictive analysis to provide early warning of potential terrorist activities. Evaluation and implementation evaluates technologies by providing test beds where new methods can be evaluated and by supporting the adoption of new tools and methods by end users. This speeds the transfer of new technologies into the hands of the analyst. The NVAC's programs help prepare scientists and engineers to accomplish the National R\&D Agenda for Visual Analytics.

URL: http://nvac.pnl.gov/ 
Organization

Parent Organization

Regulatory Power

Vision/Mission

Research Themes

Products

Primary Customers

Additional Notes
Natural Hazards Caucus Work Group

Congressional Natural Hazards Caucus

No

To develop a wider understanding within Congress that reducing the risks and costs of natural disasters is a public value. That requires educating Members and staff about the costs of natural disasters to their districts and states, and the benefits their constituents will realize through greater efforts to understand, prevent, and mitigate natural disasters.

Natural hazards

Fact sheets, briefings

Congress, Congressional Natural Hazards Caucus

URL: http://www.agiweb.org/workgroup/ 
Organization

\section{Parent Organization NATO}

Regulatory Power

Vision/Mission

Research Themes

Products

Primary Customers

Additional Notes

None
NATO Programme for Security Through Science

The NATO Programme for Security Through Science offers support for international collaboration between scientists of the countries of the Euro-Atlantic Partnership Council or the Mediterranean Dialogue. Awards are made following consideration of applications received from individual scientists in these countries. The aim of the Security Through Science programme is to contribute to security, stability and solidarity among nations by applying cutting-edge science to problem solving.

National security; anti-terrorism

Grants, expert visits, workshops, R\&D projects

International space research and policy community

NATO Science publications at http://www.nato.int/science/publications.htm\#1

Relevant book titled "Science Evaluation and Its Management" from NATO Science Series, vol. 28

URL: http://www.nato.int/science/ 
Organization

Natural Hazards Research and Applications Information Center

Parent Organization University of Colorado

Regulatory Power

Vision/Mission

Research Themes

Products

Primary Customers

Additional Notes

No agencies concerned with reducing damages caused by disasters

Natural hazards, terrorism grants, workshop, journal, list-serve

Academic community and practitioners

Products include:
To strengthen communication among researchers and the individuals, organizations, and

Newsletters (Disaster Research and Natural Hazards Observer), Web site, archive, report

- Natural Hazards Observer: http://www.colorado.edu/hazards/o/

- Disaster Research newsletter: http://www.colorado.edu/hazards/dr/

- HazLit database and search engine

- Quick Response grants

- Lists all research programs in natural hazards research

URL: http://www.colorado.edu/hazards/ 
Organization Science in Society Program

Parent Organization New Zealand Ministry of Research, Science, and Technology

Regulatory Power None

Vision/Mission Development of different communication processes. The work program has an emphasis on 3 different communication processes to meet the different needs of New Zealanders: dialogue between science and community awareness of science and technology promotion of science and technology

Research Themes Needs assessments; stakeholder research

Products Reports

Primary Customers Public

Additional Notes This group performs needs assessments, perception studies, and research with stakeholders; http://www.morst.govt.nz/?CHANNEL=SCIENCE+IN+SOCIETY\&PAGE=Science +in+Societ $y$ 
Organization Nicholas School for the Environment - Faculty/Experts Database

Parent Organization Duke University

Regulatory Power None

Vision/Mission None

Research Themes Environmental science

Products On-line database

Primary Customers Media

Additional Notes Web site is a good example of how the USGS can be promoting its scientists

URL: http://www.env.duke.edu/people/faculty/ 
Organization

Parent Organization

Regulatory Power

Vision/Mission

Research Themes

Products

Primary Customers

Additional Notes
Office of Science and Technology Policy

Executive Office of the President

None

The OSTP's continuing mission is set out in the National Science and Technology Policy, Organization, and Priorities Act of 1976 (Public Law 94-282). It calls for OSTP to serve as a source of scientific and technological analysis and judgment for the President with respect to major policies, plans, and programs of the Federal Government.

The Act authorizes OSTP to:

- Advise the President and others within the Executive Office of the President on the impacts of science and technology on domestic and international affairs;

- Lead an interagency effort to develop and implement sound science and technology policies and budgets;

- Work with the private sector to ensure Federal investments in science and technology

contribute to economic prosperity, environmental quality, and national security;

- Build strong partnerships among Federal, State, and local governments, other countries, and the scientific community;

- Evaluate the scale, quality, and effectiveness of the Federal effort in science and technology.

All issues related to science and technology; recent reports: agroterrorism, energy efficiency, homeland security, nanotechnology, animal genomics, climate change,

speeches, testimonies, press releases, federal register notices, reports

The President of the United States

Organizational chart at http://www.ostp.gov/images/orgchart2.jpg;

URL: http://www.ostp.gov/ 
Organization

Parent Organization National Institute of Health

Regulatory Power

Vision/Mission

Yes
Office of Science Policy and Planning

Serves as the principal resource for science policy, analysis, and development at NIH on issues of significance to the agency and the medical research community;

- Addresses cross-cutting science policy issues and drafts the agency approach and position;

- Provides leadership in developing major analyses of broad planning issues affecting the programs and policies of the major program components of NIH;

- Participates in the development of new policy and program initiatives in emerging research areas;

- Organizes periodic reviews of aspects of Institute and Center programs for the OD/NIH and assessment of NIH's research program under the Government Performance and Result Act;

- Plans and organizes major conferences involving the interface between science and public policy;

- Prepares special studies and reports required by the OD/NIH;

- Serves as principal staff resource in the OD/NIH for identifying and reporting on agency research opportunities and accomplishments;

- Conducts directly and through contractors, economic analyses of key programs and policy issues anticipated to be relevant to emerging planning needs of $\mathrm{NIH}$; and

- Provides ad hoc and continuing staff assistance on a wide range of substantive topics to the $\mathrm{OD} / \mathrm{NIH}$.

Research Themes

Human health

Products

Conferences, policy reports,

Primary Customers

Government, health researchers

The Economic Studies Program (ESP) within OSP includes analysis and support of studies in four general areas: 1) influence of disease burden and research opportunities on the allocation of funds within the NIH budget; 2) contributions of NIH research to increasing life expectancy, maintaining or enhancing health-related quality of life, and reducing the costs of illness and injury; 3) contributions of NIH to other national goals, such as economic growth and international competitiveness; and 4) cost and efficiency of conducting NIH-sponsored research and providing an adequate long-term supply of high-quality scientific investigators, equipment, and facilities.

URL: http://ospp.od.nih.gov/ 
Organization

Parent Organization

Regulatory Power

Vision/Mission
Office of Science Policy and Technology Transfer

Centers for Disease Control and Prevention (CDC)

None

CDC Goal: To promote health and quality of life by preventing and controlling disease, injury, and disability. OSPTT Goal:

- Maintaining the integrity and productivity of CDC's scientists by resolving controversial scientific issues, developing scientific policies and procedures, supporting training and information exchange, and presenting awards for outstanding scientific efforts

- Assuring the protection of human subjects in public health research

- Integrating behavioral and social sciences research into public health research

- Promoting and facilitating the timely transfer of technology, knowledge, products, and processes that improve public health

- Coordinating governmental and nongovernmental vaccine activities, including vaccine research, development, and safety and efficacy testing through the National Vaccine Program Office; manages the National Vaccine Advisory Committee

- Advising the Secretary of HHS and the Director of CDC about the most appropriate use of vaccines and immunization practices for effective disease control in the population; regularly reviews immunization practices and recommends improvements to national immunization efforts; manages the Advisory Committee on Immunization Practices

- Managing the CDC and ATSDR Specimen and Data Bank, an archive of biological materials, including blood components, tissue, bacterial isolates, DNA, and other biological and environmental specimens

- Coordinating efforts to integrate health information and surveillance systems in public health
Research Themes

Products

Primary Customers

Additional Notes
CDC: diseases, environmental health; OSPTT: Advisory comm., Animal Policy, Excellence in Science Comm, Human Subjects; Science Integrity, Tech Transfe

FAQs, weekly reports, journal, trainings, databases, training partnerships, research centers

general public

FAQs: http://www.cdc.gov/doc.do?id=0900f3ec80093d70

Providing Information:

- Morbidity and Mortality Weekly Report

- Emerging Infectious Disease Journal.

- National Vital Statistics System - key indicators of health from birth and death certificates

- National Health Interview Survey

- National Health and Nutrition Examination Survey.

- Behavioral Risk Factor Surveillance System (BRFSS)

- Youth Risk Behavior Surveillance System (YRBSS)

- Public Health Training Network

- 7 Centers of Excellence for Birth Defects Prevention Research across the country

Partnership programs:

- Prevention Health and Health Services Block Grant

- HIV prevention programs

- Bioterrorism Preparedness and Response Program

- REACH 2010 program - provides funding to support community-based coalitions

- Stop TB Initiative

- Global HIV/AIDS initiative, Leadership and Investment in Fighting an Epidemic (LIFE).

- National Syphilis Elimination Plan

- A Public Health Action Plan to Combat Antimicrobial Resistance

URL: http://www.cdc.gov/od/ads/ 
Organization

\section{Parent Organization}

Regulatory Power

Vision/Mission

Research Themes

Products

Primary Customers

Additional Notes
Oregon Natural Hazards Workgroup (ONHW)

Community Services Center, University of Oregon

None

The Partners for Disaster Resistances: Oregon Showcase State program provides a comprehensive framework for government and the private sector to prepare for and minimize the risk and impact of natural hazards. Specifically, the mission of the Showcase State Initiative is to: Prevent injuries and deaths, protect public and private property and create a disaster-ready statewide economy through public and private partnerships

Natural hazards, mitigation, response, preparedness planning

Web archive, training workshops

Public sector planning, emergency management practitioners

The ONHW sets up and facilitates training workshops on development of hazard mitigation plans; provides web-based archive of mitigation activities in Oregon; has performed user needs assessments of practitioners in Oregon (ex. Goal 7 Planning implementation)

URL: http://darkwing.uoregon.edu/ onhw/ 
Organization

\section{Parent Organization}

Regulatory Power

Vision/Mission

Research Themes

Products

Primary Customers

Additional Notes

\section{Pacific Disaster Center}

\section{East-West Center}

None

To provide applied information research and analysis support for the development of more effective policies, institutions, programs, and information products for the disaster management and humanitarian assistance communities of the Asia Pacific region and beyond.

Decision and Policy Support; Institutional Capacity Development; Risk and Vulnerability; Humanitarian Assistance; Security and Sustainability

PDC Automated Tsunami Alert System, Hawaii, Integrated Decision Support Systems, mitigation plans

Disaster managers and local and regional level

Funding from U.S. government appropriations (DOD), Asian and Pacific Governments, private agencies, individuals and corporations. Connected to East-West Center

See overview publication: PDC_Overview.pdf

Articles:

1. C. Chiesa, C. Laben, and R. Cicone, 2003, An Asia Pacific Natural Hazards and

Vulnerabilities Atlas, Proceedings, International Symposium on Remote Sensing of

Environment, Honolulu, November.

2. Richard Cicone, Chris Chiesa, Tom Parris, and Douglas Way, 2003, Geospatial Modeling to Identify Populations Vulnerable to Natural Hazards, Proceedings, International Symposium on Remote Sensing of Environment, Honolulu, November.

3. C. Chellis, C. Chiesa, R. Shirkhodai, Pacific Disaster Center, 2003, Integrated Decision Support System Architecture Study, Prepared for the U.S. Southern Command Humanitarian Assistance Program, May.

4. Ray Shirkhodai, 2003, Hazard Clearinghouse and a Decision Support Capability white paper, prepared for Hawaii State Earthquake Advisory Committee.

5. "Integration of Remote Sensing Data and Geographic Information System Technology for Emergency Managers and their Applications at the Pacific Disaster Center, Craig Laben, Optical Engineering, Journal for the International Society for Optical Engineering, Vol. 41, No. 9, September 2002.

6. Pacific Disaster Center: Information Resources and technology Supporting Disaster Management in the Asia-Pacific Region Peter Colvin, Contingency Planners of the Pacific Quarterly Meeting, Bank of Hawaii, Honolulu, November.

7. A Distributed Information Network Supporting Natural Hazards Applications in the AsiaPacific Region, Chris Chiesa, United Nations Regional Workshop on the Use of Space Technology for Disaster Management for Asia and the Pacific in Bangkok, November 11-15, 2002.

URL: www.pdc.org 
Organization

\section{Parent Organization}

Regulatory Power

Vision/Mission

Research Themes

Products

Primary Customers

Additional Notes
Policy Studies Institute-Environmental Group

Independent subsidiary to the University of Westminster

None

The PSI Environment Group is dedicated to the analysis of the socio-economic causes of environmental impacts and the policies that may ameliorate them. It seeks to undertake policyrelevant research of the highest quality with a view to contributing to the maintenance and enhancement of the environment's contribution to human welfare, now and in the future.

Environment, Policy, Employment

Publications and tools, events and conferences

Academia, policy makers

Their research project focuses on the role of science in environmental policy making. Much of there research can be considered basic research. A minority of their research may be considered Science Impact. Sample research projects include the Sustainable Development Research Network and the Deliberative Mapping project. Income is derived from funds for individual research projects received from a variety of sources, including government departments

URL: http://www.psi.org.uk/ 
Organization

Parent Organization

Regulatory Power

Vision/Mission

Research Themes

Products

Primary Customers

Additional Notes
RAND Science and Technology Policy Institute

RAND Corporation, Managed by the Institute of Defense Analysis

None

The Science and Technology Policy Institute (S\&T PI) is a federally funded research and development center (FFRDC) that provides analytic support to the White House Office of Science and Technology Policy (OSTP). It was chartered by an act of Congress in 1991 and began operation in 1992.

U.S. R\&D Portfolio and International Cooperation, Space and Transportation, Critical Infrastructure and Information

Technology, cont. below

research, policy advise, databases, publications

White House Office of Science and Technology Policy

Objectives:

1) assembly of timely and authoritative information regarding significant developments and trends in science and technology research and development in the United States and abroad 2) analysis and interpretation of such with particular attention to the scope and content of the federal science and technology research and development portfolio as it affects interagency and national issues

3) initiation of studies and analyses of alternatives available for ensuring the long-term strength of the United States in the development and application of science and technology, including appropriate roles for the federal government, state governments, private industry, and institutions of higher education in the development and application of science and technology.

RAND Science and Technology (S\&T) conducts multi-disciplinary research and analysis on policy issues that have scientific or technological dimensions. RAND S\&T work helps clients: 1) Assess the likely consequences of policy decisions in science and technology areas 2) Understand the science and technology components of broader issues, such as homeland security and education

3) Use scientific knowledge and technological tools to accomplish goals and improve the costeffectiveness of operations in areas such as space, energy, environment, and information technology.

URL: http://www.rand.org/scitech/stpi/ 
Organization Science and Policy Program

Parent Organization American Geophysical Union

Regulatory Power None

Vision/Mission None listed

Research Themes Climate, education, earth history, space science, natural hazards

Products

Position papers, links to research projects, congressional fellowship program

Primary Customers General public, media, educators, Congress

Additional Notes This is a summary of AGU actitivites on Capital Hil with links to research and education material; basic outreach Web site

URL: http://www.agu.org/sci_soc/policy/ 
Organization

Parent Organization

Regulatory Power

Vision/Mission
Science and Technology Directorate

Department of Homeland Security

Yes

We will lead the unified national effort to secure America. We will prevent and deter terrorist attacks and protect against and respond to threats and hazards to the nation. We will ensure safe and secure borders, welcome lawful immigrants and visitors, and promote the free-flow of commerce. Strategic Goals include:

- Awareness -- Identify and understand threats, assess vulnerabilities, determine potential impacts and disseminate timely information to our homeland security partners and the American public.

- Prevention -- Detect, deter and mitigate threats to our homeland.

- Protection -- Safeguard our people and their freedoms, critical infrastructure, property and the economy of our Nation from acts of terrorism, natural disasters, or other emergencies.

- Response -- Lead, manage and coordinate the national response to acts of terrorism, natural disasters, or other emergencies.

- Recovery -- Lead national, state, local and private sector efforts to restore services and rebuild communities after acts of terrorism, natural disasters, or other emergencies.

- Service -- Serve the public effectively by facilitating lawful trade, travel and immigration.

- Organizational Excellence -- Value our most important resource, our people. Create a culture that promotes a common identity, innovation, mutual respect, accountability and teamwork to achieve efficiencies, effectiveness, and operational synergies.

Research Themes

Homeland security, emergency preparedness

Advisory committee, national research centers, fact sheets, think tanks

General public; government

DHS primarily contracts out funds for research and has no in-house researchers.

DHS has developed Homeland Security Centers of Excellence -

http://www.dhs.gov/dhspublic/display?theme $=53 \&$ content $=3561$, think tanks:

http://www.dhs.gov/dhspublic/display?theme $=53 \&$ content $=3506$ and university partnerships

http://www.dhs.gov/dhspublic/display?theme $=53 \&$ content $=3516$

URL: http://www.dhs.gov/dhspublic/display?theme $=53$ 
Organization

Parent Organization

Regulatory Power

Vision/Mission

Research Themes

Products

Primary Customers

Additional Notes
Scottish Universities Research and Advice

funded by the Scottish Higher Education Funding Council

None

The SUPRA interdisciplinary network provided policy-related research and advisory services for Scotland, the UK and internationally. It became an internationally recognised authority on the conduct and management of interdisciplinary research and advised a wide range of organisations on the integration of natural and social science disciplines in research and policy contexts.

Science, technology, health, environment, policy

Training, advice, publications and reports,

Scottish Executive, OST, Economic and Social Research, Royal Commission on Environment, EU, Forestry Comm., OECD

SUPRA engages with policy issues relating to: agriculture \& land use, biotechnology, , chemicals, pesticides, energy, food, health technology, ICT \& Multimedia, sustainable energy and water

Interesting articles available on Web site:

- SUPRA_Foresight to Multilevel Governance Structure.pdf

- SUPRA_Abstract_Gearing Technology and Science into Knowledge.pdf

- SUPR_Abstract_Assessing End Use Relevance of Public Sector Research Organisations.pdf

URL: http://www.supra.ed.ac.uk/index.html 
Organization

\section{Parent Organization}

Regulatory Power

Vision/Mission

Research Themes

Products

Primary Customers

Additional Notes
Stockholm Environmental Institute (SEI)

University of York

None

SEI's mission is to support decision-making and induce change towards sustainable development around the world by providing integrative knowledge that bridges science and policy in the field of environment and development.

Atmospheric Pollution Strategies, Global Change Ecology, Implementing Sustainability, Water and Development

Papers, reports, books, factsheets, brochures,

Academia, decision makers

The SEI Is a multi-disciplinary group including biologists, ecologists, geographers, social scientists and spatial analysts. Staff expertise includes: air pollution in developing countries, air pollution impact modeling, GIS, integrated environmental and strategic assessments, citizen participation, urban environment, trace gas emission inventories, carb sequestration studies, dev and application of ecological footprints, policy process analysis, natural resource relationships, water resources and aquatic ecosystems. Example papers include:

- $\quad$ Forrester, J. and S. Cinderby (2002 "Computer Modelling and Local Governance:

- Challenges for 'Citizen Science'" at the Science and citizenship in a global context: challenges from new technologies conference at the Institute of Development Studies, Brighton, December 2002.

- $\quad$ Forrester, J., Potts, L. and Rosen, P. (2002) "Creating Science's 'New Social Contract"' at the European Association for the Study of Science \& Technology (EASST) conference Responsibility Under Uncertainty, in conference proceedings.

URL: http://www.york.ac.uk/inst/sei/welcome.html 
Organization

Parent Organization

Regulatory Power

Vision/Mission

Research Themes

Products

Primary Customers

Additional Notes
Sustainability Research Institute

University of Leeds, School of Earth and Environment

None

The Institute is dedicated to the development and application of environmental analysis in realization of the principles of sustainable development:

1. Entailing innovative and integrative approaches: at and between local, regional, national and international levels;

2. Developing policy contributions: connecting environmental knowledge to public and private sector decision making; and

3. Enabling socio-economic benefits: from improved community-based management and sustainable livelihood provision to enterprise initiatives and business solutions.

Environmental risk, Environment and Development

Education, publications,

Academia

Research focuses on 1) Environmental Risk (ex. certitude and scientific uncertainty; trust and social risk acceptance; management implications; decision making tools; knowledge management initiatives; risk and sustainability) and 2) Environment and Development (ex. Land degradation assessment approaches, integrating soil, ecological and community-based participatory methodologies, assessing the potential for participatory environmental monitoring and evaluation to contribute to improved community-based natural resource management projects). Article of interest: LIFE_Social Vulnerability and Ecological Fragility.doc - Building bridges between social and natural sciences

URL: http://www.env.leeds.ac.uk/research/life/ 
Organization

\section{Parent Organization}

Regulatory Power

Vision/Mission

Research Themes

Products

Primary Customers

Additional Notes
Tyndall Center for Climate Change Research

University of East Anglia

None

The Tyndall Centre aims to deliver tangible outputs and to develop partnerships between researchers on the one hand, and governments, businesses, civil society and households on the other. It is active in both the UK and in emerging parallel initiatives around the world, such as the European Climate Forum.

integrated climate change research, engagement with national/international stakeholders, education

publications, events, media, research

Researchers, academia, policy makers

Research addresses both climate change mitigation and adaptation policy objectives with a particular emphasis on integrated assessment. Most importantly, its research applies across a range of scales in space and time - from the domestic to the global, and from the present through the coming centuries. It is funded by the UK Dept. of Trade and Industry, Natural Environment Research Council, Economic and Social Research Council, Engineering and Physical Science Research Council.

URL: http://www.tyndall.ac.uk/ 
Organization

Parent Organization

Regulatory Power

Vision/Mission

Research Themes

Products

Primary Customers

Additional Notes
U.K. Climate Impacts Programme

Department for Environment, Food \& Rural Affairs, Oxford University

No

to co-ordinate and integrate an assessment of the impacts of climate change at a regional and national level that is led by stakeholders. This means that our stakeholders or partners commission the research and determine the research agenda, ensuring that it meets their needs. UKCIP provides support and guidance throughout the process for both stakeholders and the researchers, so providing a bridge between the researchers and the decision-makers in government organisations and business.

Climate change impacts, socio-economic and physical modeling

Tools, workshops, presentations, publications, advisory panel, map products

Stakeholders, government

Tools include: Climate Scenarios, Socio-economic scenarios, handling risk and uncertainty, costing the impacts of climate change. ECI undertakes issue-driven policy relevant research to inform the management of environmental change and has a strong focus of energy research undertaken by their Low Carbon Futures team. The work includes projects on policy formulation, energy efficiency, cleaner energy, consumer behaviour, sustainability and equity, fuel switching, solar technologies, renewable energy and carbon waste management. The Environmental Change Institute also coordinates the UK Climate Impacts Programme (UKCIP) funded by Defra. UKCIP aims to co-ordinate and integrate an assessment of the impacts of climate change at a regional and national level that is led by stakeholders. Its stakeholders, or partners, commission the research and determine the research agenda, ensuring that it meets their needs. UKCIP provides support and guidance throughout the process for both stakeholders and the researchers, so providing a bridge between the researchers and the decision-makers in government organisations and business.

URL: http://www.ukcip.org.uk/ 
Organization

\section{Parent Organization}

Regulatory Power

Vision/Mission

Research Themes

Products

Primary Customers

Additional Notes
U.K. Public Engagement Programme

Engineering and Physical Sciences Research Council (EPSRC)

No

Generating engagement between the research community and the general public is a key part of our mission. Such engagement stimulates the public's interest in research, inspires future generations of researchers and fosters mutual understanding, helping the research base evolve in tune with the changing needs of a more informed society.

Research Funding on getting science to general public, activities for youth and teachers

Grants

General public

The Public Engagement Programme's objectives are:

- To support and encourage the EPSRC research community to engage with the general public.

- To convey to young people the creativity and excitement of research and the rewards of relevant educational opportunities so as to encourage them into related careers.

- To stimulate public interest in advances and issues in engineering and physical sciences research to contribute to a more informed society.

- To build partnerships with other stakeholders, in particular other Research Councils, and look for opportunities for greater integration of activities.

Research funding is for: (1) Partnerships for Public Awareness (PPA) Awards are intended to support high quality public awareness projects by EPSRC researchers.

(2) Senior Media Fellowships (SMFs) offer high value fellowships to free up time for leading researchers to pursue opportunities within the mass media.

(3) Public Communications Training Funds (PCTFs) provide an optional $£ 500$ addition to research grants to support public communications training.

PPA guide at: (see PPAGuide.pdf)

:http://www.epsrc.ac.uk/ContentLiveArea/Downloads/Adobe\%20Portable\%20Document\%20

Format/PPAGuide1.pdf

URL: http://www.epsrc.ac.uk/Web site/default.aspx?ZoneID=5\&MenuID=118 
Organization

Parent Organization

Regulatory Power

Vision/Mission

Research Themes

Products

Primary Customers

Additional Notes
Science and Society, Office of Science and Technology

U.K. Office of Science and Technology

None

The concept of Science and Society recognizes the increasing impact of science on our everyday lives and reflects a move away from a traditional paternalistic one-way provision of information to the public and towards engagement and dialogue with civil society on science and the issues it raises for individuals and society. The aim is to achieve greater public involvement in the debate about the place of science in society.

Policy

PUSET: grants, publications, research on public perception of science, conferences

HM government

This is the main science organization for the United Kingdom. It focuses on science funding, science policy, and science and society. Science and Society is one of four divisions. OST is headed by the Chief Scientific Adviser who provides advice to the Government on science, engineering and technology (SET) matters. Headed by the Chief Scientific Adviser who provides advice to the Government on science, engineering and technology (SET) matters

Interesting documents available on the Web site:

For Guidelines: OST_Guidlines2000.doc

For Science Advisory Committee codes: OST_CodeOfPractice.pdf

Foresight Program: http://www.foresight.gov.uk/

URL: http://www.ost.gov.uk 
Organization

Parent Organization

Regulatory Power

Vision/Mission

Research Themes

Products

Primary Customers

Additional Notes
Public Engagement with Science and Technology

U.K. Office of Science and Technology

None

The objectives of the Public Engagement Team are to:

- increase public awareness of the role of science in society and everyday life;

- promote public engagement with and dialogue about science in society;

- inform policy-making and public engagement strategies by identifying public attitudes to science; and,

- increase the impact of public engagement and science communication activities in the UK by promoting and enabling collaboration, co-operation, networking and dissemination of best practice within the science communication community

Interaction with stakeholders

Publications

Policymakers, general public

Group does needs assessments; reports on science and society; interaction of stakeholders in science

Guidelines on dialogue with the Public: http://www.rcuk.ac.uk/guidelines/dialogue/

Publications

1. Dialogue with the Public: Practical Guidelines (publ August 2002): A guide for two-way communication between science and the public, published by OST and Research Councils UK. 2. Going Public (publ Sept 1996): an introduction to communicating science, engineering and technology

3. Science and the Public (publ October 2000): a review of science communication and public attitudes to science in Britain.

4. Science Connections (publ Aug 2003 in electronic form only): a guide to the science communication activities of a variety of key organisations.

5. Science in Society report (107Kb)(publ Nov 2002): this report, commissioned by OST, recommends how an overview of the range and effectiveness of science communication activities in the UK can be obtained.

6. Science in Society report - OST response (publ April 2003) : OST response along with details of the public consultation.

7. Science in Society report - public consultation outcome (448 Kb)(publ September 2003) :outcome of the consultation along with OST's implementation plans.

8. The Public Consultation on Developments in the Biosciences (publ May 1999): a report investigating public attitudes to developments in the biological sciences and their oversight. 9. Wolfendale Report (publ Oct 1995): report of the committee to review the contribution of scientists and engineers to the public understanding of science, engineering and technology. URL: http://www.dti.gov.uk/ost/ostbusiness/puset/puset.htm 
Organization Woodrow Wilson International Center for Scholars

Parent Organization Smithsonian Institution

Regulatory Power None

Vision/Mission To unite the world of ideas to the world of policy by supporting pre-eminent scholarship and linking that scholarship to issues of concern to officials in Washington.

Research Themes

international development

Products

radio program, reports, has own publishing press, newsletters, working papers, Web site

Primary Customers government officials

Additional Notes

The Center is a public-private partnership. Approximately one third of the Center's operating funds come annually from an appropriation from the U.S. government, and the Center's building, a wing of the Ronald Reagan Building, was provided by the U.S. government. The remainder of the Center's funding comes from foundations, grants and contracts, corporations, individuals, endowment income, and subscriptions.

URL: http://wwics.si.edu 